Hydrol. Earth Syst. Sci., 17, 1871-1892, 2013

www.hydrol-earth-syst-sci.net/17/1871/2013/

doi:10.5194/hess-17-1871-2013

(C) Author(s) 2013. CC Attribution 3.0 License.

\title{
A framework for global river flood risk assessments
}

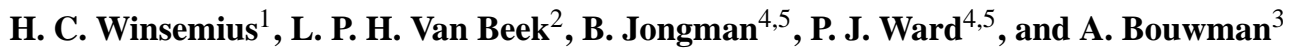 \\ ${ }^{1}$ Deltares, P.O. Box 177, $2600 \mathrm{MH}$, Delft, the Netherlands \\ ${ }^{2}$ Department of Physical Geography, Utrecht University, P.O. Box 80115, 3508 TC, Utrecht, the Netherlands \\ ${ }^{3}$ PBL, The Netherlands Environmental Assessment Agency, P.O. Box 303, 3720 AH, Bilthoven, the Netherlands \\ ${ }^{4}$ Institute for Environmental Studies, Faculty of Earth and Life Sciences, VU University, De Boelelaan 1087, 1081 HV, \\ Amsterdam, the Netherlands \\ ${ }^{5}$ Amsterdam Global Change Institute, VU University, De Boelelaan 1087, $1081 \mathrm{HV}$, Amsterdam, the Netherlands \\ Correspondence to: H. C. Winsemius (hessel.winsemius@deltares.nl)
}

Received: 15 August 2012 - Published in Hydrol. Earth Syst. Sci. Discuss.: 21 August 2012

Revised: 9 April 2013 - Accepted: 10 April 2013 - Published: 21 May 2013

\begin{abstract}
There is an increasing need for strategic global assessments of flood risks in current and future conditions. In this paper, we propose a framework for global flood risk assessment for river floods, which can be applied in current conditions, as well as in future conditions due to climate and socio-economic changes. The framework's goal is to establish flood hazard and impact estimates at a high enough resolution to allow for their combination into a risk estimate, which can be used for strategic global flood risk assessments. The framework estimates hazard at a resolution of $\sim 1 \mathrm{~km}^{2}$ using global forcing datasets of the current (or in scenario mode, future) climate, a global hydrological model, a global flood-routing model, and more importantly, an inundation downscaling routine. The second component of the framework combines hazard with flood impact models at the same resolution (e.g. damage, affected GDP, and affected population) to establish indicators for flood risk (e.g. annual expected damage, affected GDP, and affected population). The framework has been applied using the global hydrological model PCR-GLOBWB, which includes an optional global flood routing model DynRout, combined with scenarios from the Integrated Model to Assess the Global Environment (IMAGE). We performed downscaling of the hazard probability distributions to $1 \mathrm{~km}^{2}$ resolution with a new downscaling algorithm, applied on Bangladesh as a first case study application area. We demonstrate the risk assessment approach in Bangladesh based on GDP per capita data, population, and land use maps for 2010 and 2050. Validation of the hazard estimates has been performed using the Dartmouth Flood Observatory database. This was done by comparing
\end{abstract}

a high return period flood with the maximum observed extent, as well as by comparing a time series of a single event with Dartmouth imagery of the event. Validation of modelled damage estimates was performed using observed damage estimates from the EM-DAT database and World Bank sources. We discuss and show sensitivities of the estimated risks with regard to the use of different climate input sets, decisions made in the downscaling algorithm, and different approaches to establish impact models.

\section{Introduction}

There is increasing attention in the scientific and policy communities for strategic global assessments of natural disaster risks. For example, the United Nations International Strategy for Disaster Risk Reduction (UNISDR) now coordinates the production of the two-yearly Global Assessment Report (GAR) on Disaster Risk Reduction (UNISDR, 2009, 2011), which provides a global overview of risk and risk reduction efforts, and analyses of the underlying trends and causes of risk. Furthermore, risk due to extreme events and disasters are at the core of the Managing the Risks of Extreme Events and Disasters to Advance Climate Change Adaptation (SREX) report of the Intergovernmental Panel on Climate Change (Field et al., 2011). Global risk assessments are required by International Financing Institutes to assess which investments in natural disaster risk reduction are most promising to invest in; by intra-national institutes for monitoring progress in risk reduction activities, for example those 
related to the implementation of the Hyogo Framework for Action (UNISDR, 2005); by (re-)insurers, who need to justify their insurance coverage; and by large companies to assess risks of regional investments.

UNISDR (2011) defines disaster risk to be a function of hazard, exposure, and vulnerability. Hazard refers to the hazardous phenomena itself, such as a flood event, including its characteristics and probability of occurrence; exposure refers to the location of economic assets or people in a hazard-prone area; and vulnerability refers to the susceptibility of those assets or people to suffer damage and loss (e.g. due to unsafe housing and living conditions, or lack of early warning procedures). Throughout this paper, we have used the same terminology as UNISDR (2011).

The GAR2009 and GAR2011 reports show current estimates of global risk in terms of fatalities and economic exposure for several natural disasters, as well as trends in disaster risk over the past few decades. Extending these global risk assessments to include future changes in both natural disaster frequency and intensity (for example due to climate change) and socioeconomic conditions are seen as a research priority (e.g. Field et al., 2011). Such assessments would allow societies and the previously mentioned stakeholders to develop and consider different options for disaster risk reduction. The results of global risk assessments may in particular be used to compare risks from region to region in order to decide which region deserves the most commitment to the development of risk reduction measures or mitigation procedures in a changing future.

Flood damage constitutes about a third of the economic losses inflicted by natural hazards worldwide and floods are, together with windstorms, the most frequent natural disasters (Munich Re, 2010; UNISDR, 2009). It therefore has a prominent place in the GAR2011 report, where flood hazard is based on a methodology published by Herold and Mouton (2011). The concentrated nature of floods makes them predictable in an operational context such as flood forecasting, because forecasts may be tailored to specific, known flood-prone locations and a short lead time is sufficient to act (see e.g. Carsell et al., 2004; Verkade and Werner, 2011; Weerts et al., 2011; Werner et al., 2005). At the global scale, the local character and short timescale of floods makes prediction difficult, because global data and models are generally tailored to relatively coarse spatial (and to a smaller degree temporal) resolutions. Moreover, the impact of local scale floods is dependent on the spatial overlap between a flooded area and the exposed assets and inhabitants in the region. The spatial variability of such exposures is often large, and there are many examples where they are in fact concentrated in flood-prone regions. The coarse resolution of global hazard data and model outputs (e.g. around 0.5 degree scale) should therefore be tailored to smaller scales such as $1 \mathrm{~km}$ before they can be meaningfully combined with exposure and vulnerability indicators, useful for the abovementioned stakeholders.
In this paper, we propose a global flood risk assessment framework for river floods. The framework is based on global hydrological models and global impact assessment models, so that future scenario flood risk may be estimated as well. The framework acknowledges the spatial variability in both exposure and flood hazard, under the limitation that global hydrological models generally have a coarse scale resolution. In short, the framework proposes a model cascade of:

- global forcing datasets of the current (or in scenario mode, future) climate;

- a global hydrological model;

- a global flood routing model; and

- an inundation downscaling model to establish probability distributions of annual flood extremes as a measure of flood hazard.

A second component of the framework combines these hazards with modelled flood impacts (e.g. damage, affected GDP, affected population) at a high enough resolution to establish global indicators for flood risk for the envisaged end users, mentioned above. The framework allows for the inclusion of regionally variable knowledge on flood vulnerability, through the use of spatially variable impact models. The framework itself is presented in Sect. 2. In this section we also demonstrate our implementation of the framework, using a selected model cascade. We present results of our implementation in Bangladesh in Sect. 3. We discuss issues such as sensitivities of choices in the modelling cascade, applicability, and potential improvements of our application in Sect. 4. Here we also describe open research questions related to the choices made in the modelling chain and invite other researchers or modellers to contribute to these open questions. Finally a number of conclusions of our research are drawn in Sect. 5.

\section{Description of flood risk assessment framework and implementation in GLOFRIS}

\subsection{General risk framework}

Generally, risk is estimated as an annual expected impact (e.g. damage), being the integral of the probabilities of nonexceedance of certain hazardous events, multiplied by the consequence of the event (see e.g. Verkade and Werner, 2011). If this is done on an annual basis using annual extremes of hazardous events (common in flood risk assessment), this integral can be written as

$$
R=\int_{p=0}^{1} D_{\theta}(p) \mathrm{d} p,
$$




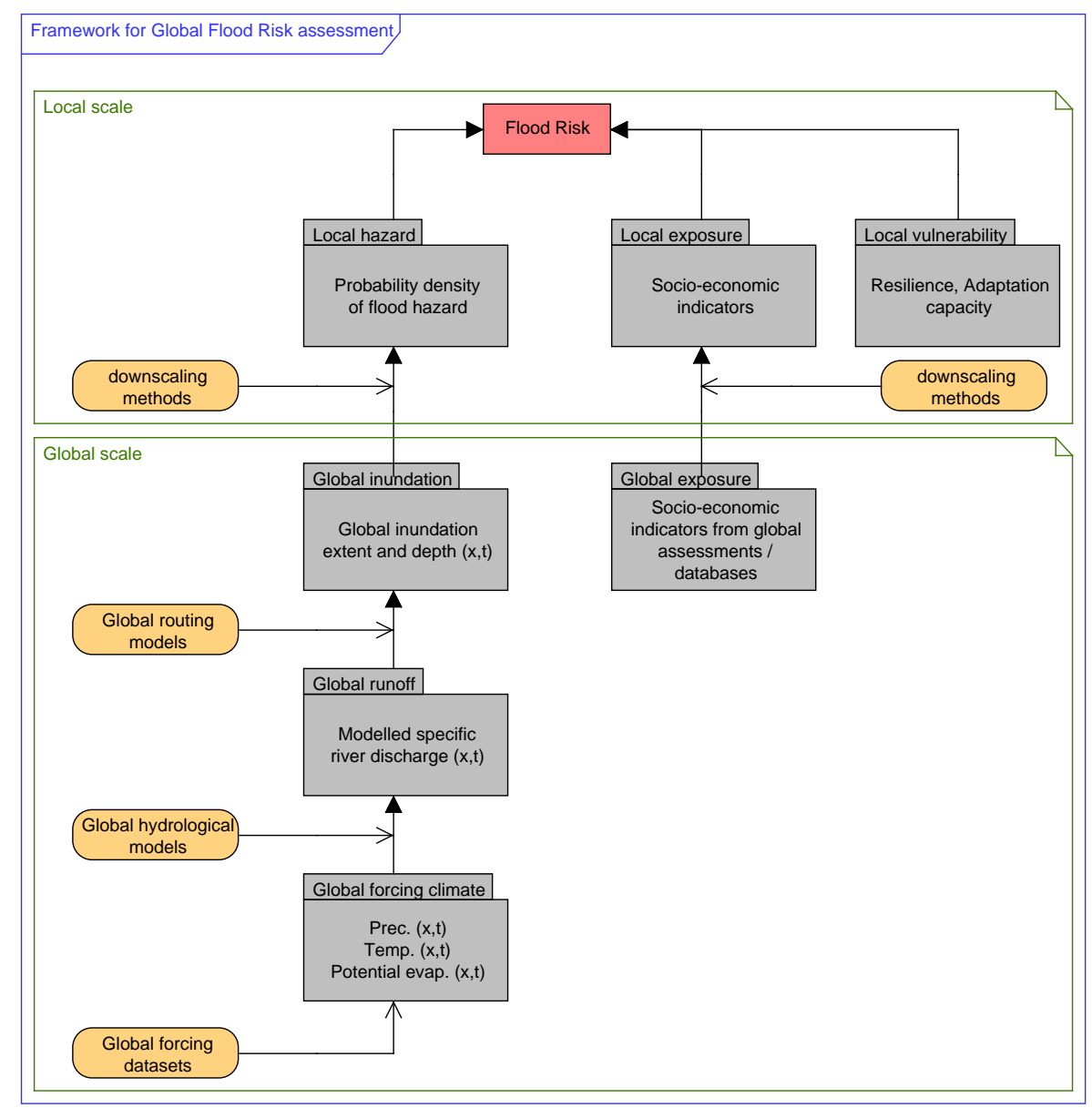

Fig. 1. Schematic of framework for global flood risk assessment.

where $R$ is the annual expected impact (risk), $D$ is an impact or damage model, potentially consisting of both direct and indirect, tangible and intangible components, associated with an event, along with certain event characteristics such as flood levels, extents, and durations, with annual probability of non-exceedance $p[1 / T]$. Finally, $\theta$ represents a number of fixed-in-time socio-economic factors, which determine how easily an area is affected by floods (i.e. the vulnerability). Such factors eventually determine the shape of $D$ (De Bruijn, 2005). In short, $D_{\theta}$ combines the exposure and vulnerability within an area into a damage function. In flood risk estimation, "events" are typically associated with annual timescales, meaning that not more than one extreme event along with consequences can take place within a year. The consequence $D_{\theta}$ of the event with likelihood $p$ can be expressed in a plethora of indicators, reflecting for instance damage (see e.g. Merz et al., 2010), affected people, loss of lives (Jonkman, 2007) and health impact (Tapsell et al., 2002). The associated vulnerability determining factors, $\theta$, may be different per consequence of interest, depending on the type of consequence, models used to estimate them, and socio-economic circumstances such as the level of education, poverty, insurance coverage, and measures in place to improve resilience (e.g. dikes, flood zoning, and flood early warning procedures).

For a global river flood risk assessment, the components used in Eq. (1) need to be estimated at the global scale, at any position of interest on the earth, and at a sufficient resolution, in order to be compatible with the spatial scale at which flood events occur and have impact. Summarised, these components include: (a) the probability distribution function $p$ of flood event characteristics; (b) the maximum exposure (i.e. maximum value of $D$ ); and (c) the factors $\theta$, determining vulnerability and hence the shape of $D$. A crucial part of the framework is that hazard, exposure, and vulnerability should be established at a high enough spatial resolution to allow for their combination into a risk estimate that is meaningful to end users, operating at global scale (see Sect. 1). This is important because if inundation occurs somewhere in a large grid box (e.g. $50 \times 50 \mathrm{~km}^{2}$, a typical scale of a global hydrological model), this inundation only causes damage when the exposure within this grid box occurs at the same position within the grid box. 
Figure 1 shows an overview of our suggested framework. At the top we show the envisaged end result, being flood risk estimates at a resolution appropriate to accommodate both the spatial variability of the flood process and the factors determining the degree of exposure and vulnerability. Towards the bottom, we show the components that lead to the envisaged end-result. In these components, two major parts can be distinguished:

- the part in which hazard is determined in current and/or future conditions. This part requires a global hydrological model, along with a set of meteorological input time series, and a global routing model, which explicitly accounts for inundation of river surroundings. Finally, it requires a spatial downscaling of inundation to a resolution appropriate for global flood risk estimation; and

- the part wherein exposure is determined in current and future conditions. This information generally comes from state-of-the art high-resolution maps of typical exposure indicators such as population and GDP, combined with future projections of these indicators. These future projections are generally much coarser and require downscaling approaches as well, to estimate flood risk.

The individual components of the framework and how these were established in this study are further described in the remaining subsections. We developed an implementation of the framework called "GLObal Flood Risk with IMAGE Scenarios" (GLOFRIS). In this application, we made a choice in the proposed model cascade, which is described along with the general framework. This choice is certainly not exclusive and potential sensitivities in this choice and possible alternatives are therefore discussed in Sect. 4.

\subsection{Estimating global flood hazard probabilities}

The flood probability of non-exceedance $p$, in Eq. (1) needs to be derived from either observations, or from model simulations. At a global scale, the only observations that are likely to provide such information with large enough density and spatial resolution are remote sensing observations (e.g. Brakenridge et al., 2003; Prigent et al., 2007). The Dartmouth Flood Observatory (DFO) is until now the only comprehensive dataset of homogeneous flood observations that could meet the objectives outlined in this study. The flood hazard mapping method described by Herold and Mouton (2011) also heavily relies on this database. DFO produces flood maps at $250 \mathrm{~m}$ resolution over a moving window archive of MODIS Aqua and Terra satellite imagery. Besides a nearreal-time service, DFO also stores records of flood maps that have potential for use in global risk studies. The problems of current satellite observations in view of flood risk estimation are: (a) that the collected time series are generally not long enough to provide an estimate of the current flood inundation probability distribution function $p$; (b) that only inundation extent (and not depth) is provided; (c) that the data do not allow a user to make future projections of flood risk under climatic and/or man-made change; and (d) that, although a moving average archive is used, images are potentially partly obscured by clouds, which may render hazard estimates based on the statistics of the database too positive. Cloudy conditions are in fact to be expected during significant flood events.

\subsubsection{Global hydrology: PCR-GLOBWB}

To estimate global flood exposure probabilities, we therefore propose to use a global hydrological modelling cascade instead. Such a modelling cascade was also recently proposed by Pappenberger et al. (2012). These models are potentially biased, uncertain, and of low spatial resolution, but they do have the potential to provide long time series of flow and inundation conditions, which lead to an estimate of the probability distribution of flow characteristics, and provide consistent spatial information. Importantly, they have the ability to provide future projections when forced with scenario data.

In Table 1, we present the requirements of the model, as well as the input datasets to the model, in order to provide the required information. The table also presents justifications for the presented requirements. We discuss potential alternatives to the choices made in this study in Sect. 4.

In GLOFRIS, we have decided to use the macro-scale hydrological model PCR-GLOBWB. This model represents the terrestrial part of the global hydrological cycle by means of a regular grid and discrete time steps, typically with a spatial resolution of $0.5^{\circ}$ and daily temporal resolution on the global scale. More details are given in Van Beek and Bierkens (2009); Bierkens and Van Beek (2009). This model obeys the requirements given in Table 1. PCR-GLOBWB has not been calibrated, but it has been validated on discharge (Van Beek et al., 2011a) and on GRACE satellite data of terrestrial water storage (Wada et al., 2012). Generally, the model showed fair to good performance and no tuning was carried out in order to maintain the same globally consistent parameterization.

The required forcing was established using a $30 \mathrm{yr}$ (19611990) combination of gridded monthly in situ observations of the Climate Research Unit (New et al., 2002) combined with the ECMWF $40 \mathrm{yr}$ re-analysis (ERA40, Uppala et al., 2005). This dataset obeys the requirements that monthly volumes are represented as much as possible, while the temporal variability is included as well. The procedure to combine both datasets is described by Sperna Weiland et al. (2010).

\subsubsection{Global hydraulics: PCR-GLOBWB dynamic routing}

To convert the specific discharges from global hydrology, a river routing is required that includes overbank storage. One 
Table 1. Required model characteristics.

\begin{tabular}{|c|c|c|}
\hline Characteristic & Value & Justification \\
\hline Forcing & $\begin{array}{l}>30 \text { yr daily dataset, comprised of ob- } \\
\text { servations, in which the day-to-day } \\
\text { variability and auto-correlation is pre- } \\
\text { served as much as possible. Reanalysis } \\
\text { records, in which precipitation observa- } \\
\text { tions are assimilated, can also be used. }\end{array}$ & $\begin{array}{l}\text { In particular, precipitation should be volumetrically as } \\
\text { accurate as possible, but should also contain the tem- } \\
\text { poral characteristics of rainfall, because flood genesis } \\
\text { is typically dependent on multi-day rainfall accumula- } \\
\text { tions. }\end{array}$ \\
\hline Model time step & (Sub)-daily & $\begin{array}{l}\text { Runoff generation is a highly non-linear process, and } \\
\text { should be resolved at sufficiently short timescales. Fur- } \\
\text { thermore flood propagation over typical grid cell sizes } \\
\text { used in global hydrology occurs at daily or even sub- } \\
\text { daily timescale. }\end{array}$ \\
\hline Potential evaporation scheme & Radiation-based approach & $\begin{array}{l}\text { Haddeland et al. (2011) showed that a non-radiation- } \\
\text { based approach may result in overestimation of poten- } \\
\text { tial and thus actual evaporation during storm (and hence } \\
\text { flood) periods. }\end{array}$ \\
\hline Runoff scheme & $\begin{array}{l}\text { Infiltration excess as non-linear } \\
\text { function of soil moisture }\end{array}$ & $\begin{array}{l}\text { A non-linear relation with soil moisture provides the } \\
\text { most realistic runoff generation in time and therefore } \\
\text { the best hydrograph shape. }\end{array}$ \\
\hline Routing & $\begin{array}{l}\text { Dynamic routing with sub-grid variable } \\
\text { overbank elevation }\end{array}$ & $\begin{array}{l}\text { A dynamic routing, which differentiates river flow from } \\
\text { overbank flow, is required to simulate sub-grid flood } \\
\text { extent and depth. This component can be a separate } \\
\text { model, forced by the outputs of a global hydrological } \\
\text { model. }\end{array}$ \\
\hline
\end{tabular}

of the first published attempts at global inundation modelling (also applied in the model cascade by Pappenberger et al., 2012) was performed by Yamazaki et al. (2011). They established a sub-grid variable global river routing model, called CaMa-Flood, which describes floodplain inundation dynamics based on a subgrid-variable parameterisation of floodplain topography. The output of this routing model is water storage, water level, flooded area, and routed discharge within each 0.25 degree grid cell and each (daily) time step. The output inundation dynamics of such a global river routing model may be used to establish an estimation of global flood statistics, i.e. a probability distribution function of flood characteristics $p$, but do not deliver this in the required detail for a risk assessment. This requires higher resolution information on flood statistics.

In GLOFRIS we use the PCR-GLOBWB extension for dynamic routing DynRout. It is similar to the procedure of Yamazaki et al. (2011) in that it converts the sum of specific discharge and the direct gains and losses from PCRGLOBWB in river discharge, as well as overland flow in flood plain areas outside the river banks, resulting in a temporally variable inundation extent. The model schematizes the maximum channel storage based on geomorphological laws, that do not take any safety measures into account (Allen et al., 1994). Compared to the method of Yamazaki et al. (2011), DynRout uses a kinematic wave approximation rather than the diffusion wave approximation. The DynRout method was introduced earlier in Petrescu et al. (2010). While this implementation shows more realistic travel times and flood attenuation than routing without explicit consideration of flood plains, further validation is ongoing. The theory and parameterisation of the DynRout extension are further described in Appendix A.

\subsubsection{Flood statistics}

To derive annual flood extremes within GLOFRIS, PCRGLOBWB and DynRout have been run over the $30 \mathrm{yr}$ period (1961-1990) using the aforementioned input set based on CRU and ERA40. As a further demonstration of the framework in a changing climate, two future conditions were derived using GLOFRIS by running the hydrological model with the ECHAM5 and HadGEM2 model outputs in the 2050 climate conditions, forced by the IPCC SRES A1B scenario. Bias correction of precipitation and temperature has been applied on the 2050 time series prior to running the model. For temperature a monthly additive bias correction was used based on the monthly means. For precipitation, first the number of wet days was corrected, as GCMs are notorious for producing false drizzle (e.g. Piani et al., 2009). Then, a multiplicative correction on the monthly mean rainfall was established. The annual flood probability distribution of the current and future series is estimated by assuming that each 
annual extreme has an equal probability of occurrence. This principle forms the probability distribution of flood characteristics $p$ (see Eq. 1) at the $0.5 \times 0.5 \mathrm{deg}$. resolution in current and future climate. To this end we have extracted the annual maximum daily flood volume in each grid cell, resulting in 30 global maps of daily flood volumes per climate condition. The flood volume represents the amount of water potentially residing outside the river banks. In the next subsection, we describe how we distribute this flood volume over the river's surroundings at $1 \times 1 \mathrm{~km}^{2}$ scale.

\subsubsection{Downscaling of floods to appropriate resolution}

The major problems of using outputs from global hydrological models for flood risk estimation are:

- The outputs of hydrological models are biased due to errors in model inputs, in particular rainfall, and uncertainties in the parameterisation of dominant hydrological processes (see e.g. Haddeland et al., 2011).

- There are uncertainties in the parameterisation of the river channel dimensions. In particular, no information on natural or man-made levees is included in such models. Parameterisations of natural embankments and associated channel dimensions are generally assumed, for instance by assuming a linear scaling between outlet dimensions and upstream dimensions (Decharme et al., 2008) or an empirical relationship with long-term runoff (Yamazaki et al., 2011). In reality, populated areas often have a higher man-made embankment to decrease the frequency of flooding.

- The spatial resolution is generally not adequate for global flood risk estimation ( $\sim 0.5$ degrees $)$, as mentioned in Sect. 2.1. Within each cell, the distribution of socio-economic conditions as well as flood hazard may be large. Data on socio-economics, required to estimate $D$, are typically available at resolutions of $1 \times 1 \mathrm{~km}^{2}$ in the current conditions, making $1 \times 1 \mathrm{~km}^{2}$ a more appropriate scale for global flood risk assessment. $1 \times 1 \mathrm{~km}^{2}$ was also identified as the minimal resolution for floodplain mapping according to Blyth (1997). Note that for other purposes than global risk assessments, $1 \times 1 \mathrm{~km}^{2}$ may be considered a low resolution. However, we focus here on the perspective of a global scale assessment, where large scale decisions are of interest to the end user.

For these reasons, an approach is required that reduces errors in runoff generation and the effect of poorly estimated river channel dimensions in populated areas, while at the same time increasing the resolution of the results to a meaningful spatial scale. To this end, we propose a downscaling of the global model results to a local scale inundation estimate. This downscaling may then be applied on any region, for which flood risk estimates are relevant. This could be done, for example, at the country or basin scale. To handle the aforementioned problems, the downscaling should consist of the following steps:

- The coarse-scale global modelled time series of flood volumes should be post-processed into annual statistics of maxima, resulting in a coarse scale probability distribution of flood events. Depending on whether a dynamic or steady-state downscaling method is used, respectively, a short (e.g. monthly) time series around each flood event or the static annual maximum should be retrieved from the daily time series.

- An assumption about non-impact floods must be made. This assumption is required because the channel dimensions, used to model floodplain flow at the global scale, are generally based on some geomorphological relationship, assuming e.g. natural channel conditions (in many cases this may result in an exaggeration of the amount of water moving over the floodplains, with respect to the amount of water moving through the river channel. The non-impact flood volume can be established by assuming that an event flood volume with a pre-defined probability of non-exceedance $p_{\text {thres }}$ (or return period $\left.1 / p_{\text {thres }}\right)$ is not impacting on the surroundings of the river. This assumption reflects: (a) the fact that a given volume of water (or other characteristics, important for flood risk estimation) associated with a return period safety level $1 / p_{\text {thres }}$ is captured by the presence of manmade embankments or flood retention areas; or (b) the fact that a flood with the return period $1 / p_{\text {thres }}$ does not cause damage or any other negative impact, or even can be beneficial to the surroundings. This is for instance the case in areas where rice cultivation relies on annual flooding (see e.g. De Bruijn, 2005). The value for $p_{\text {thres }}$ is preferably selected using local knowledge of flood protection measures. The reduced volumes associated with the probability distribution function $p$ are calculated as

$$
V_{\lim }(p)=\max \left[V(p)-V\left(p_{\text {thres }}\right), 0\right],
$$

where $V_{\text {lim }}(p)$ is the reduced flood volume for each probability $p$, and $V$ ( $\left.p_{\text {thres }}\right)$ is the threshold volume, occurring with probability $p_{\text {thres }}$ at which no flood impact may be expected. This equation implies that a flood event with a probability of non-exceedance smaller than $p_{\text {thres }}$ has no negative impact on the river's surroundings and results in a downscaled flood map of zero depth everywhere.

- The reduced volumes $V_{\lim }(p)$ are downscaled over the full empirical probability distribution, using a highresolution Digital Elevation Model (DEM), using either a static downscaling approach (a suggestion is given below) or a more sophisticated dynamic inundation model 

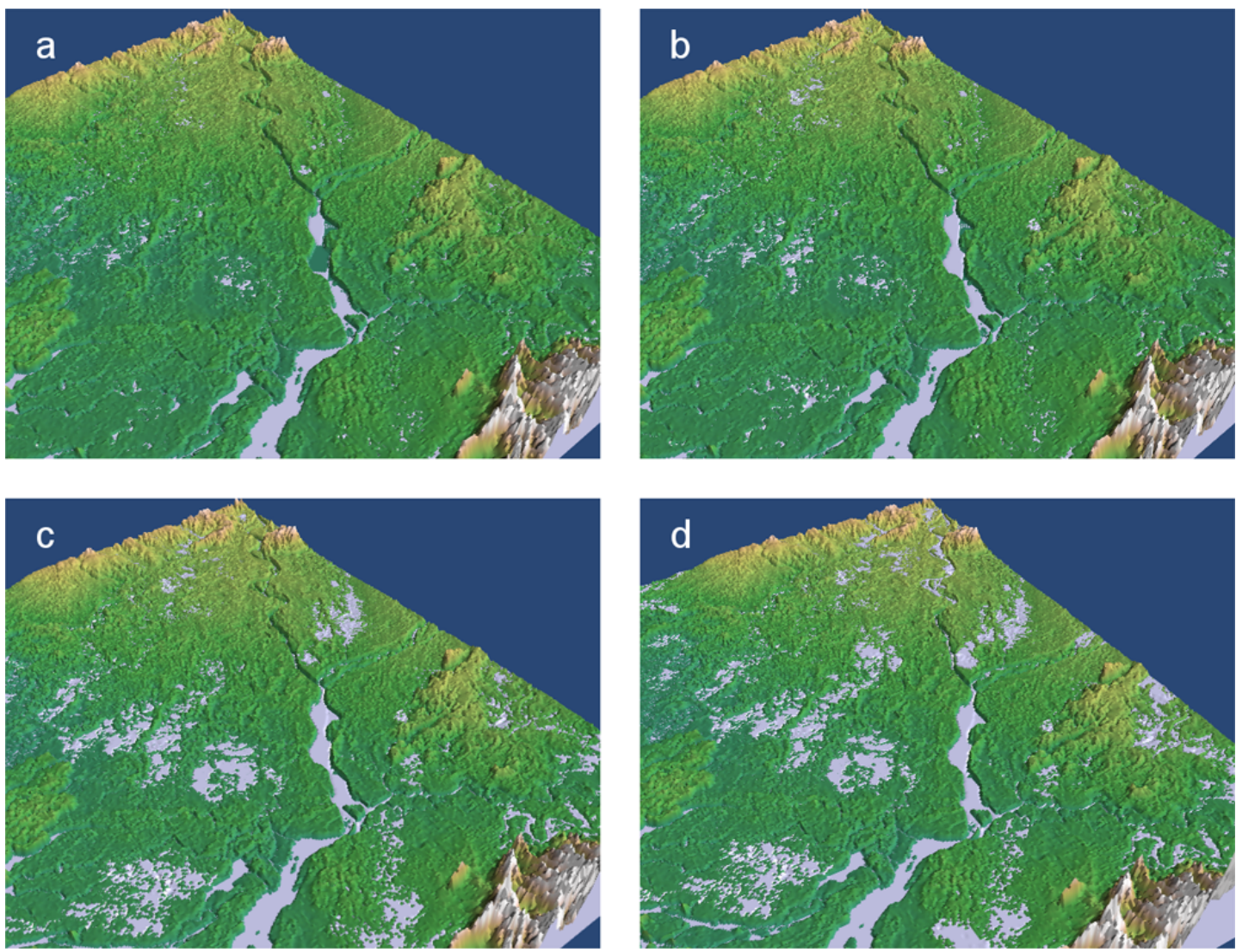

Fig. 2. An illustration of the sequential leveling of river water levels with the surrounding connected pixels over a part of Bangladesh on a $1 \times 1 \mathrm{~km}$ elevation grid. The examples shown here are computed using the once-in-30 yr flood from the ERA40/CRU reference scenario; assuming flooding from stream order 6 and higher; a levee height, conform to a recurrence interval of 0 yr (i.e. the total volume from DynRout is considered): (a) leveling with $10 \mathrm{~cm}$ of water, (b) $20 \mathrm{~cm}$ of water, (c) $2 \mathrm{~m}$ of water, some areas have stopped filling, (d) $10 \mathrm{~m}$ of water.

of the region. (see e.g. Neal et al., 2012) The minimum prerequisite of the downscaling procedure is that it should be mass conservative. If the preferred downscaling method requires discharge, besides or instead of the flood volume, then the discharge should also be reduced following the abovementioned method, assuming that a part of the discharge with probability $p_{\text {thres }}$ remains within the river banks.

In GLOFRIS, we apply a static downscaling on the annual extreme volumes from PCR-GLOBWB. As mentioned before, the framework is not exclusive to the use of the method described below.

The principle idea of our downscaling approach is to impose a certain water elevation above the level of the river itself on river cells within a 0.5 degree pixel, and evaluate which upstream connected cells have a surface elevation lower than the imposed elevation in the river channel. These cells then receive a water layer, equal to the water elevation minus the surface elevation of the cell under consideration. This procedure is repeated with increasing water levels, until the flood volume, imposed in the upstream cells, equals the water volume, generated by the global model in its $0.5 \times 0.5$ degree river cells. A cell is considered to be a "river cell" (i.e. a cell that can contribute to fluvial flooding) when it contains a stream with a catchment area or a stream order (Strahler, 1964) larger than a certain user-defined threshold. Below this threshold, the stream is not considered to be significant enough to cause river flooding. In the smaller regions, flooding is assumed to be more of a pluvial or flashy nature and should be estimated from other processes than river flooding. The downscaling procedure is illustrated in Fig. 2. For one 0.5 degree pixel, the water depth within a single $1 \times 1 \mathrm{~km}^{2}$ area can be written as follows:

$d(x, y, p)=\max \left[h\left(x_{n}, y_{n}, p\right)-z(x, y), 0\right]$,

where $d[\mathrm{~L}]$ is the water depth in a $1 \times 1 \mathrm{~km}^{2}$ pixel, $x$ and $y[\mathrm{~L}]$ represent the $x$ and $y$ coordinate of the $1 \times 1 \mathrm{~km}^{2}$ pixel, $h[\mathrm{~L}]$ is the water level relative to a fixed datum (e.g. mean sea level) at the nearest river cell (i.e. at location $x_{n}, y_{n}$ ), and $z[\mathrm{~L}]$ is the surface elevation of the pixel under consideration. Note that within one 0.5 degree area, there are multiple river pixels $1 \times 1 \mathrm{~km}^{2}$, all defined according to the upstream area threshold. Equation (3) implies that the flood water from a 
$0.5 \times 0.5$ degree area inundates cells starting from all river cells in the $0.5 \times 0.5$ degree area upwards, drowning any areas from the rivers cells upwards that are lower than the water level in the nearest river pixel. The mass, generated at the 0.5 degree scale, is conserved within the downscaling by selecting water levels at the $1 \times 1 \mathrm{~km}$ river pixels in the $0.5 \mathrm{de}$ gree area, which give the following closure:

$\sum d(x, y, p) A(x, y)=V_{\lim }(p)$.

The correct value for $d$ is iteratively estimated with stepsizes of $0.1 \mathrm{~m}$. Our downscaling procedure ensures that the computed volume of flooded water from PCR-GLOBWB is accounted for and is therefore mass conservative. To generate a probability distribution of flood water levels, the downscaling routine uses the discrete extreme value distribution of flooded volumes, computed as presented in Sect. 2.2.3 as input. The result is 30 high-resolution estimates of water level maps with given probability of non-exceedance (return period), representing the fluvial flood hazard at an appropriate resolution.

\subsection{Estimation of exposure and vulnerability indicators}

\subsubsection{Introduction of methods}

In the framework, flood risk is defined as a product of hazard, exposure, and vulnerability (UNISDR, 2009). The hazard is represented by the hydrological model cascade (e.g. within GLOFRIS) in the appearance of flood extent and depth. In this section we will discuss the possible incorporation of exposure and vulnerability indicators in the framework.

Exposure to a flood event can be subdivided into physical exposure, defined as the number of people and assets affected by the event, and the resulting economic exposure (Peduzzi et al., 2009). Economic exposure is represented by the total value of assets in the affected area, which can be estimated using several methodologies. Existing local and regional methodologies calculate exposure in terms of asset values or maximum damage values per individual property or square metre of specified land use (Jongman et al., 2012a; Merz et al., 2010; Messner et al., 2007; Smith, 1994). These asset values are determined using detailed empirical damage data from past flood events or analysis of synthetic (what-if) scenarios (e.g. Green et al., 2011).

Because detailed spatial data are not available on a global scale, exposure indicators for global impact assessment are inevitably more generalised. Since asset values are directly related to GDP per capita (Green, 2010), a combination of population density and GDP data can be used as an indicator for the total value of assets (Peduzzi et al., 2009). An important limitation to this approach is that GDP per capita is an average of total national income, while the spatial differences are substantial (Hill, 2000). An alternative approach is the upscaling of existing regional approaches. Jongman et al. (2012b) have achieved this by taking asset values per square metre calculated for the Netherlands; calculating the values for other countries on the basis of the relative GDP per capita difference; and applying the resulting square metre figures to a global urban density map. A limitation of this approach is that the regional model is designed on the basis of a high-resolution land use map with various categories, while the global data is relatively coarse and has only one "urban" class. This results in a large degree of generalisation.

Vulnerability defines to what extent the exposed people and assets are adversely affected by the flood event (Jha et al., 2012; UNISDR, 2011). With increasing vulnerability, the exposed assets will be affected to a larger degree. The accepted standard method for including local vulnerability in land-use-based flood risk assessment is the use of depthdamage curves (Green et al., 2011). Depth-damage curves are mathematical functions representing the percentage loss of the total asset value with increasing inundation depth. On a societal scale, important vulnerability factors that are known to influence flood impact (in no particular order of importance) are corruption, equality, bureaucratic quality, law and order, ethnic and religious tensions, government stability, and democratic accountability (Ferreira et al., 2011). Estimations of these social and governance aspects, in terms of vulnerability indicators, are available on country level for the entire world (e.g. Kaufmann et al., 2011; World Bank, 2012).

In GLOFRIS, we used two methodologies for the quantification of flood impact. The first method is based on population density and GDP per capita estimates (Sect. 2.3.2) and the second method on urban density and maximum damage estimates (Sect. 2.3.3). The first will be referred to as the population method in the remainder of this paper. The latter is referred to as the land use method. Both methodologies use high-resolution $(1 \times 1 \mathrm{~km})$ data of population, GDP per capita, and urban density distribution for current impact assessment. Projections up to 2050 are conducted using 0.5 degree resolution GDP and population estimates from the Integrated Model to Assess the Global Environment (IMAGE, Bouwman et al., 2006) and the Global Integrated Sustainability Model (GISMO, PBL, 2008). Population and GDP were derived from GISMO. IMAGE provides scenarios of population density, averaged over 24 areas, called world regions. GISMO is a spatially more explicit scenario model, and ingests IMAGE population scenarios and downscales these to a 0.5 by 0.5 degrees spatial level, based on distinctions between urban and rural areas and is provided in the current condition and different future scenarios. More details on the GISMO approach to population downscaling may be found in Van Vuuren et al. (2007). 


\subsubsection{Method 1: population-scaled GDP (population method)}

\section{Maximum exposure}

The Gross Domestic Product - Purchasing Power Parity (GDP/PPP) per capita is used as an approximation of assets. Country-averaged GDP/PPP from the World Bank's world development indicators (WDI) were used for the base year and divided over the 0.5 degree population map, assuming each individual would be equally rich. Economic growth rates from the IPCC-SRES scenarios (IPCC, 2000) were used as future scenario. Regional economic growth rates combined with the GDP per country in the base year results in GDP for the scenarios per 0.5 degree pixel.

The future 0.5 degree maps of GDP per capita were further downscaled to $1 \times 1 \mathrm{~km}^{2}$ using a detailed population map of the current situation, which is projected into the future. Three datasets make the downscaling possible: (1) the Landscan 2007 population dataset, which counts the population on a spatial scale of 30 by 30 arc seconds $\left(\sim 1 \times 1 \mathrm{~km}^{2}\right)$ for the whole world, (2) the CIESIN GPW3 GRUMP urban and rural extent dataset, which distinguish urban and rural land use; and (3) GLOBCOVER 2006, the Global Land cover database, which is used to prevent allocation of population in bare areas. The Landscan data on population is chosen instead of the Gridded Population of the World (GPW) on which the GRUMP dataset is based because of detailed resolution and advanced modelling practices (Meijer et al., 2006).

The downscaling is performed by assigning urban and rural population $1 \times 1 \mathrm{~km}^{2}$ cells within each 0.5 degree cell. These are assigned different population densities. The Landscan 2007 population data is assigned to be urban or rural by using the GRUMP urban or rural extent. For each $1 \times 1 \mathrm{~km}$ cell within a 0.5 degrees cell, the fraction of urban and rural population is calculated using the GRUMP and Landscan 2007 data. The GISMO urban and rural population at the 0.5 degrees scale were distributed over the $1 \times 1 \mathrm{~km}$ cells using the calculated fraction. Cells with urban population according to GISMO, but without urban extent according to GRUMP in the current situation, are assigned the summed urban and rural population. In case Landscan indicates no population, but GISMO does, the population is equally distributed over a cell. In case GLOBCOVER 2006 indicates bare areas, water bodies, or permanent snow and ice, no population is assigned.

\section{Vulnerability}

The most simple depth-damage function (DDF) was used. Affected GDP was assumed to increase linearly with water level from a damage of zero for a water level of zero, to a maximum affected GDP (see above) at a level of $3 \mathrm{~m}$.

\subsubsection{Method 2: land-use-based damage (land use method)}

\section{Maximum exposure}

In most flood damage modelling studies, economic exposure is based on a discrete land cover map, whereby each land cover class has a corresponding asset value. In this study, we used fractional land cover maps, which show the fraction of land within each grid cell covered by each land cover class. Since the aim of the paper is to demonstrate the potential application of flood risk modelling techniques on a global scale, we used a simple classification of land cover into three classes: high-density urban; low-density urban; and non-urban. For the reference time period (2010), we firstly used land cover data from two sources: MODIS (Schneider et al., 2009); and the GRUMP dataset (CIESIN and CIAT, 2009) to create a discrete land cover map showing urban and peri-urban areas, using the approach of Kummu et al. (2011). Secondly, we created a set of three fractional land cover maps (high-density urban, low-density urban, and non-urban). For the high-density urban map, we assumed a fractional cover of 0.75 in those cells classed as urban in the discrete land cover map (since MODIS assigns cells as urban where $50 \%$ or more of the cell is urbanised), and a fractional cover of 0 in all other cells; and then applied a linear interpolation method with a maximum distance of $5 \mathrm{~km}$ to derive a high-density urban area map with fractional values between 0 and 0.75 . For the low-density urban area map, we assumed the fractional cover to be 0.25 for those cells classed as periurban in the discrete land cover map (except where this led to a total area fraction greater than 1 when added to the urban map). The non-urban land use map was derived by subtracting both the urban and peri-urban maps from unity. For 2050, we projected the change in the percentage of high-density and low-density urban area per grid cell, based on the method developed and validated in Jongman et al. (2012b). The projection method is shown in Eq. (5), whereby $A_{\text {urban }}\left[\mathrm{L}^{2}\right]$ is the urban area per grid cell, $\rho[-]$ is the total population of the country, $v[-]$ is the fraction of the population living in urban settlements (UN, 2010), and $t$ is the specific year of analysis.

$A_{\text {urban }}(t)=A_{\text {urban }}(t-1) \frac{\rho(t) v(t)}{\rho(t-1) v(t-1)}$

The projection has been validated for the period 1970 2005 on the basis of HYDE historic urban density data (Klein Goldewijk et al., 2011). We found that the projected density using Eq. (5) has an overall $R^{2}$ of 0.99 with urban density from the HYDE data, and is significant at a $99 \%$ confidence interval. Note that we did not allow for an expansion in urban area, since such an assessment would require sophisticated land cover modelling at the global scale. Finally, we assigned an economic asset value to each land cover class, using the method applied in Jongman et al. (2012b). As a basis for 

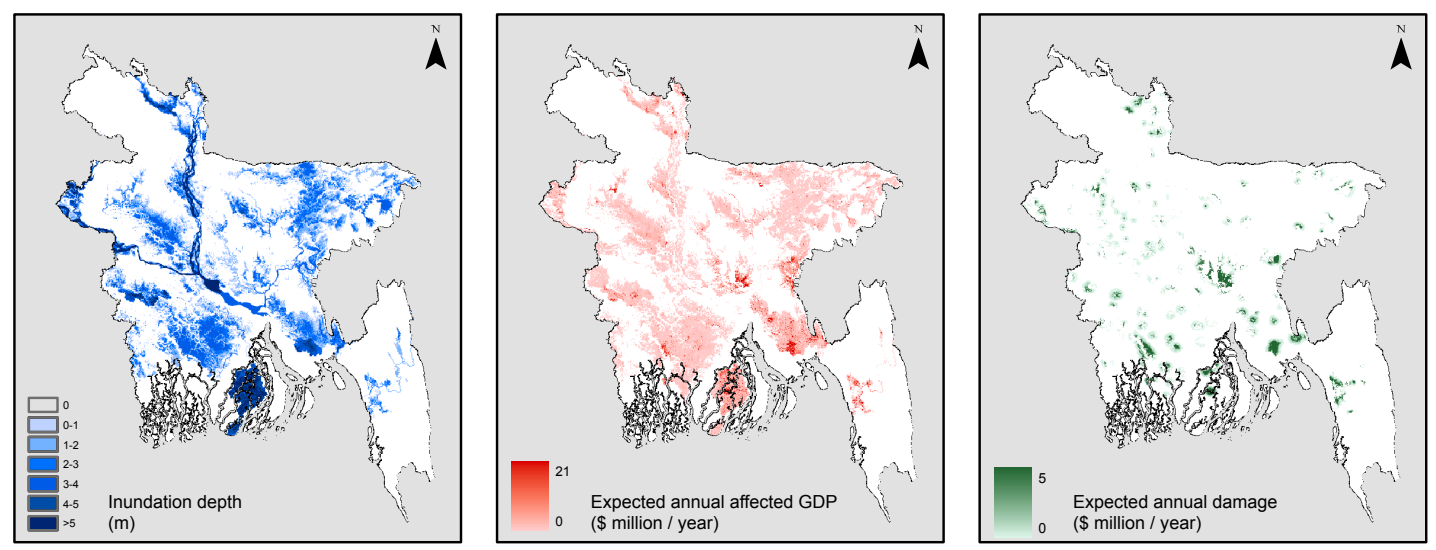

Fig. 3. From left to right: the $30 \mathrm{yr}$ flood, downscaled to Bangladesh; the expected value of annual damage (land use method); and the expected value of annual affected GDP (population method), based on the reference climate (1961-1990) and the current population, land use, and GDP.

asset values we use the figures calculated for the Netherlands in the Damage Scanner model (Klijn et al., 2007), which we adjust for each country relative to its GDP per capita at Purchasing Power Parity. For Bangladesh, the resulting asset values for 2010 and 2050, respectively are: (a) $\$ 33 \mathrm{~m}^{-2}$ and $\$ 177 \mathrm{~m}^{-2}$ for urban area; and (b) $\$ 10 \mathrm{~m}^{-2}$ and $53 \mathrm{~m}^{-2}$ for peri-urban area.

\section{Vulnerability}

Here, we use DDFs derived from the Damage Scanner (Aerts et al., 2008; Klijn et al., 2007) as a demonstration of methods. These DDFs were based on Dutch data. We apply a different DDF for urban and for peri-urban areas. Although more advanced than our first linear DDF, it should be noted that the identification of improved international vulnerability assessment methods should be a research priority (Jongman et al., 2012a).

\subsection{Risk}

Flood risk has been estimated in terms of annual expected values of affected GDP, and damage. This is done by integrating Eq. (1) using the established probability distribution of flood hazard $p$ with associated flood levels, described in Sect. 2.2, and the damage models $D$, which reflect exposure and vulnerability $\theta$ due to local asset characteristics.

\section{Results}

The steps described in the previous section lead to:

- An empirical probability distribution from $30 \mathrm{yr}$ of simulation of river flood volumes in all grid cells of the global hydrological model PCR-GLOBWB and DynRout. The model setup is described in Sects. 2.2.1 and
2.2.2, whereas the derivation of the probability distribution is given in Sect. 2.2.3.

- Localised probability distributions of river flood levels, taking into account the local discharge capacity of rivers (method described in Sect. 2.2.4).

- Localised flood risk estimates expressed as annual expected values of a certain flood impact. In this case alternative impacts are demonstrated being: the expected value of annual affected GDP, based on the population method (all equally rich); and the expected value of annual damage, established with the land use method, which focuses more on the actual asset value (described in Sect. 2.3).

To demonstrate the framework's results, we have established the downscaling and risk estimates for Bangladesh as a first application.

\subsection{Flood hazard estimation and validation}

The flood maps, of which an example is shown in the left-hand side in Fig. 3, are produced under the assumption that a $2 \mathrm{yr}$ flood is within the river's drainage capacity. Furthermore, river flooding is considered to play a role only in streams with a Strahler stream order of 6 and larger (Strahler, 1964). The sensitivity of these assumptions is further investigated in our discussion. We have performed a rough validation of the modelled flood hazard against the flood extent maps of Dartmouth Flood Observatory (DFO, http://floodobservatory.colorado.edu/). This validation is limited as the modelled once-in- $30 \mathrm{yr}$ flood is not per se fully equivalent with the DFO observed flood extent. In fact, the return periods belonging to the flood map may be different for each pixel. Furthermore, this validation does not give any information about the correctness of the frequency 


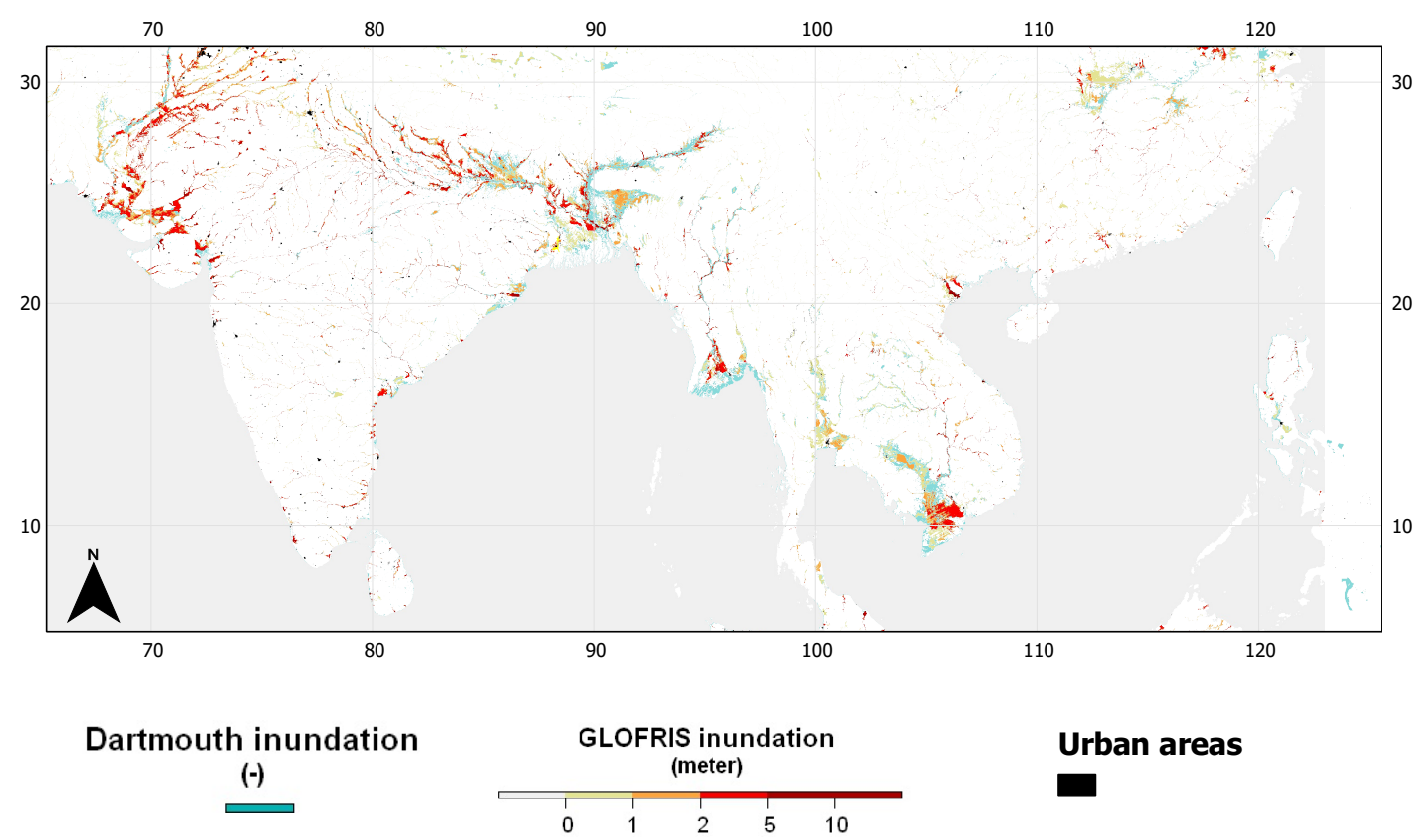

Fig. 4. Once-in-30 yr inundation according to GLOFRIS model cascade, overlaid on the Dartmouth Flood Observatory maximum inundation extent.

of occurrence of flood levels above a certain depth from our model cascade, which would require a long time series of annual extreme flood levels. DFO does not show any flood levels but merely a classification of flooded and non-flooded areas. Finally, DFO also shows floods due to impeded drainage and coastal floods, processes which are not modelled by the GLOFRIS model cascade yet.

Figure 4 shows our $30 \mathrm{yr}$ flood extent (left) as well as the maximum documented DFO flood extents over Southeast Asia. Flood extent around the large rivers such as the Ganges Brahmaputra, the Chao Phraya, Irryawaddi and the Indus are quite well estimated. It is evident that areas with probably relatively shallow inundation, further away from the main river are less well simulated. Our inundation algorithm is based on the principle that floods are generated by backwater from large rivers. In the less well-represented areas, the inundation could be caused by a different phenomenon such as overland flow or flooding by local rainfall. To improve the results in these areas, a more dynamic downscaling approach could be used, e.g. suggested by Neal et al. (2012). Coastal deltaic areas such as the lower Mekong and Ganges Brahmaputra and the coast south of the Irrawaddi are also likely to be underestimated by GLOFRIS, because coastal flooding or impacts of tidal backwater play a dominant role in these areas.

Figure 5 shows a more zoomed extent over Bangladesh. Both figures reveal a reasonable resemblance in flood patterns. In the Bangladesh case, it seems that in the southeast of the country, flood extent is somewhat overestimated while in the northeast there is some underestimation. Probably, the drainage network in the southeast, estimated by the model, is connected to the outflowing reaches, while in reality this connection does not exist. The northeast region belongs to the Hoar sub-basin and is a flash-flood-prone region with impeded drainage problems. As flash floods are not simulated by our model cascade, this could explain the underestimation here.

A further validation over Bangladesh has been performed by comparing a single event with imagery from Dartmouth Flood Observatory (DFO). The CRU-ERA40 run covers a period before the satellite era. Therefore we performed an additional run based on the ERA-Interim reanalysis dataset over a period from 1979 until 2010. The rainfall of ERAInterim was bias corrected using the Global Precipitation Climatology Project (GPCP) monthly rainfall analysis. The ERA-Interim archive is described by Berrisford et al. (2009) while the procedure for bias correction is described by Balsamo et al. (2010). We selected the summer 2004 event for validation. We used the same settings to produce flood maps, as used for the validation of a return period floods, namely a stream order threshold of 6 for significant rivers and a return period threshold for non-impact floods of $2 \mathrm{yr}$. During this event, significant flooding occurred in Northern India, Bangladesh and Myanmar. The downscaling algorithm was applied on a time series of GLOFRIS flood volumes over the period 10 July until 10 August 2004, the period during which most of the flooding occurred. The GIS layers of the same period over the event area were delivered by R. Brakenridge (personal communication, 2013) from DFO and include the following approximate dates: 13 July, 23 July, 27 July and 12 August. Note that some of the GIS layers 

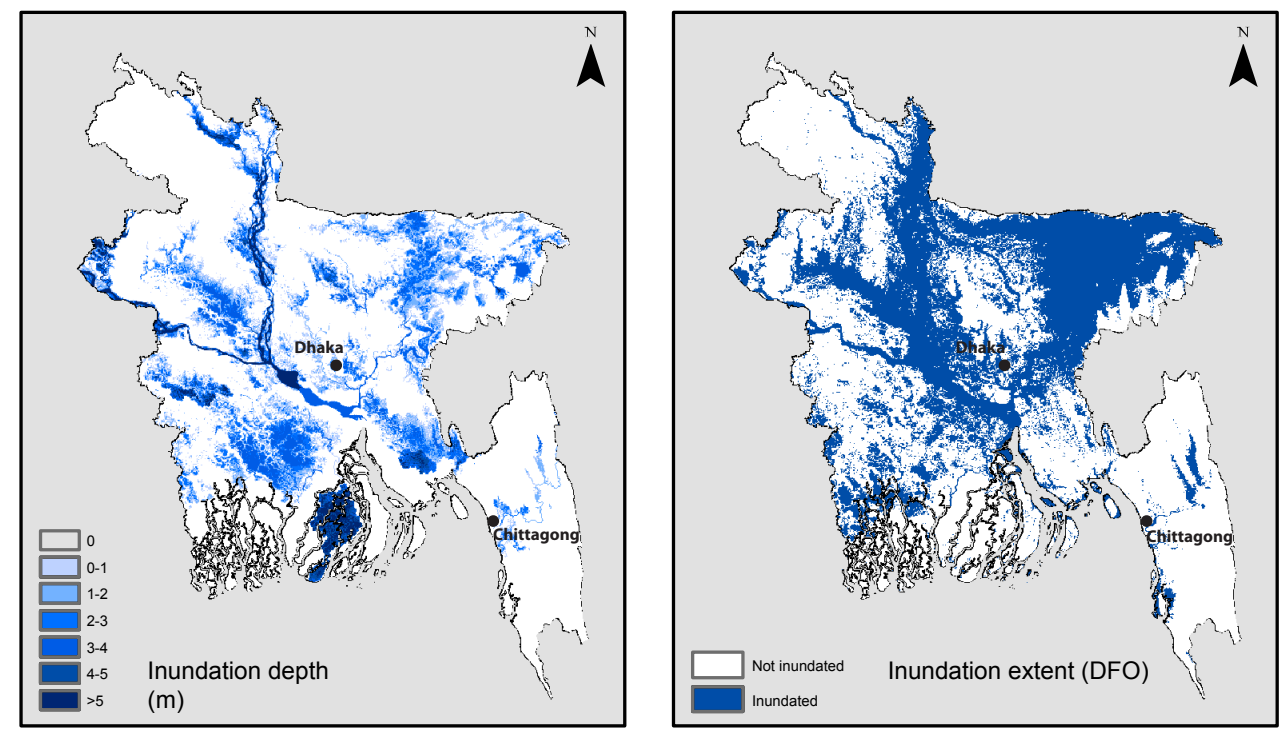

Fig. 5. Validation of flood hazard map over Bangladesh. The left subfigure shows the inundation depth of the $30 \mathrm{yr}$ return period from GLOFRIS. The right figure shows the outline of areas that have been inundated at least once on the full Dartmouth flood Observatory (DFO) record (1985-2010).

are built from a collection of images covering several days. Furthermore, cloud cover can in some cases cause misses. The left-hand side of Fig. 6 shows at which moment in time flooding has been observed for the first time in the investigated period according to DFO areal flood estimates. The right-hand side of Fig. 6 shows the same for our model cascade.

In the northwestern part of the covered region, both DFO and GLOFRIS show that flooding occurred in particular in the Koshi tributary to the Ganges River. Notably, the Ganges itself, upstream from the confluence does not flood, while in other years, this does happen. The flood volume has therefore been reasonably estimated in the different tributaries. As for timing, it seems that our downscaling algorithm estimates that flooding occurs more or less instantaneously over the whole area, connected to the Koshi river.

In the Hoar region (upstream region of the Meghna catchment), the genesis of the flood event is estimated reasonably well: i.e. the central part floods earlier than the far upstream parts in the east of the catchment. This resembles the Dartmouth observations. It should be noted however, that our model cascade predicts the flooding in the central area about 10 days later than the satellite observations indicate. It may be that within this region the water-holding capacity in PCRGLOBWB is slightly overestimated, causing flooding to start too late compared to reality. Another reason may be inaccuracies in the timing of the daily rainfall according to the ERAInterim reanalysis data. The areal extent of flooding is somewhat underestimated in the Hoar region. This may be caused by the fact that part of the flood extent is caused by smaller scale flood processes, such as excessive local rainfall combined with impeded drainage or flash flooding.

The flood extent in the upper Brahmaputra seems to be underestimated. This is probably due to the fact that relatively small rivers (i.e. smaller than the used stream order threshold) flow down from relatively steep areas in the Tibetan Plateau (North of the main river) into the lower lying floodplain, with a sudden decrease in slope. The larger flood extent is therefore probably due to flooding of the smaller tributaries.

Finally, the flood extent in the Jamuna (downstream of the Brahmaputra) is very much equal to the flood extent of the DFO satellite observations. The timing of flooding is also very much overlapping the timing of flooding of the DFO imagery. In general, the comparison between the modelled flood event and the DFO imagery shows reasonable results in terms of location and timing of flooding, especially considering the global applicability of the model cascade. The flood extent is often somewhat underestimated, which may be due to the fact that other flood processes besides river flooding play a dominant role, as well as the fact that the SRTM elevation data used has a limited horizontal and vertical resolution and accuracy.

\subsection{Risk estimation and validation}

The middle and right-hand plates in Fig. 3 show the resulting expected values of damage, based on the population method and the land use method. The spatial patterns of the risk estimates also reveal the underlying spatial heterogeneity of the risk-causing processes, being on the one hand the flood hazard, and on the other hand the distribution of GDP, land use, 

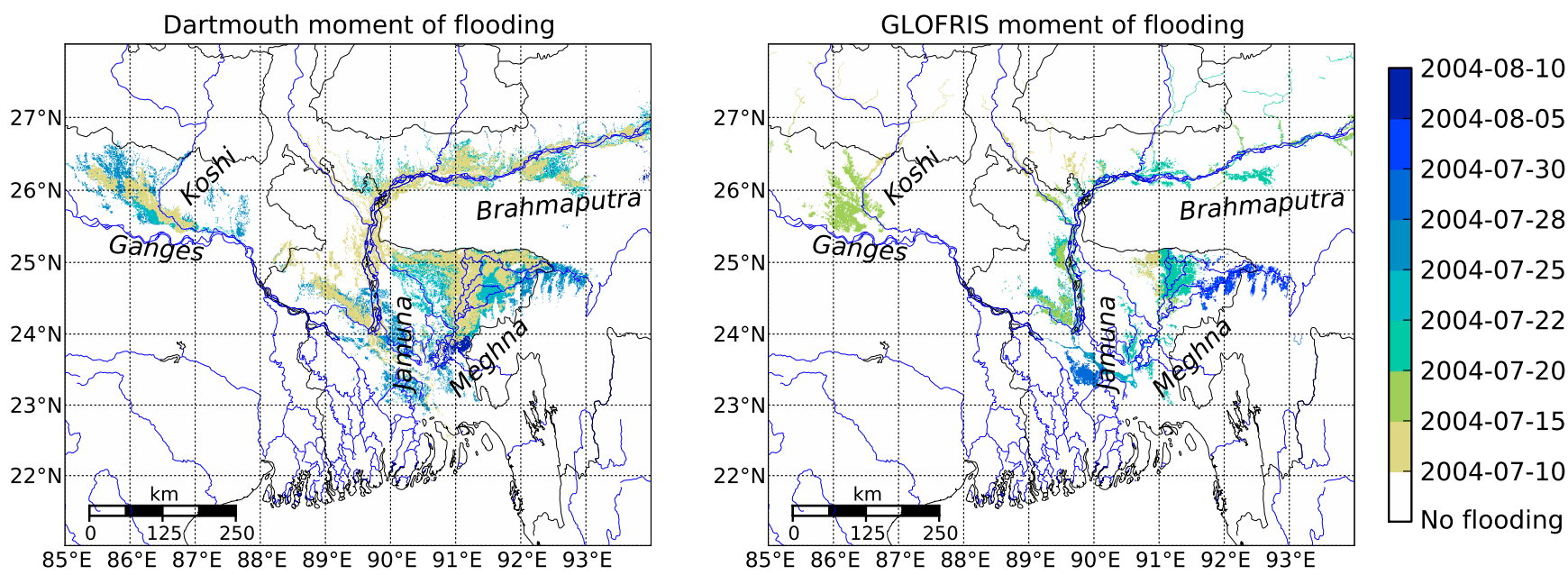

Fig. 6. Estimates of the moment of flooding during the summer of 2004 over Bangladesh and surroundings. Left: Dartmouth Flood Observatory observations, Right: GLOFRIS modelled estimates. The color scale indicates the first moment that any flooding occurs (i.e. water level $>0 \mathrm{~m})$.

Table 2. Expected annual damage (land use and population method approach) for the Bangladesh case study for the reference scenario and for the future scenarios (2050) with hazard change only (ECHAM, HADGEM), exposure change only, and hazard and exposure change combined.

\begin{tabular}{lcccccc}
\hline & \multicolumn{2}{c}{$\begin{array}{c}\text { Land use method } \\
\text { (\$PPP millions) }\end{array}$} & & \multicolumn{2}{c}{$\begin{array}{c}\text { Population method } \\
\text { (\$PPP millions) }\end{array}$} \\
\cline { 2 - 3 } \cline { 6 - 7 } Exposure scenario & Ref. asset value & 2050 asset value & & Ref. GDP & 2050 GDP \\
\hline Climate scenario & 740 & 8171 & & 2183 & 14791 \\
\hline Reference climate & 2017 & 22128 & & 6996 & 62782 \\
2050 (ECHAM) & 2701 & 30061 & & 9281 & 46327 \\
2050 (HADGEM) & & & & & \\
\hline
\end{tabular}

and population. This emphasises the importance of solving risk at an appropriate spatial scale. Naturally, the value of assets may be very independent of the population size. This explains most of the differences between the two approaches to estimate flood risk.

In Table 2 we summarise the expected annual damage (based on the population method and land use method) for the Bangladesh case study for the different hazard and exposure scenarios. In current conditions, the expected annual damage is ca. $\$ 740$ million according to the land use method, while it is $\$ 2183$ million using the population method. Under the future scenarios of hazard and exposure change, these values increase by a factor $22-30$ and $21-28$, respectively, depending on the GCM used. We see that the effects of simulated change in exposure only (increase by a factor 11 and 7 , respectively) are much higher than those of climate change only (increase by factor 3 to 4, depending on GCM and impact assessment method used), which confirms that a combination of hazard and exposure (due to land use changes) is needed to properly address future changes in flood risk (see e.g. Field et al., 2011; Wilby et al., 2008). The results for the two impact assessment methods differ by a factor of approximately 3 , while the relative differences from current to future conditions are approximately the same for the two methods. The most extreme once-in-30 yr damage in our calculations is approximately $\$ 4500$ million.

Furthermore, we have performed a limited validation of the risk results against observed damages cited in existing literature and databases. Major river floods took place in Bangladesh in 1998 and 2004. Estimates of the damages as a result of these floods can be found in the EM-DAT database (EM-DAT: The OFDA/CRED International Disaster Database - www.emdat.net - Université catholique de Louvain - Brussels - Belgium) and in the report of World Bank (2010). These values, adjusted to \$ PPP2010 values can be found in Table 3. The flood volumes of 1998 are estimated to have had a return period of $52 \mathrm{yr}$ according to the World Bank (2010) and of ca. 60-70 yr on the Brahmaputra and 30 years on the Ganges according to Monirul Qader Mirza (2003). Hence, in Table 3 we compare our results for the simulated $30 \mathrm{yr}$ return period with the observed results for 1998, noting that the actual return period in 1998 was in fact 
Table 3. Comparison of observed and simulated damages in 1998 and 2004. Note: for the 1998 flood we used the modelled results for the $30 \mathrm{yr}$ return period inundation when in reality the return period was in the order of 30-70 yr; and for the 2004 flood we used the modelled results for the $15 \mathrm{yr}$ return period inundation when in reality the return period was in the order of $20 \mathrm{yr}$. All values are in \$PPP2010.

\begin{tabular}{lrr}
\hline & \multicolumn{2}{c}{ \$PPP (2010 values) } \\
\hline Year & 1998 & 2004 \\
EM-DAT & 12313 & 6695 \\
World Bank (2010) & 6093 & 5660 \\
Modelled damage (land use approach) & 4635 & 3415 \\
Modelled damage (population method) & 16837 & 11995 \\
\hline
\end{tabular}

higher. For 2004, the World Bank (2010) estimated the flood volume to have a return period of $20 \mathrm{yr}$. The closest available simulated return period within our empirical distribution in our study is $15 \mathrm{yr}$, and hence in Table 3 we show these figures for the simulated values in 2004. The simulated damage (land use approach) is of the same order of magnitude as the observed results, though it is somewhat lower. However, this is to be expected since: (a) the simulated return period is $30 \mathrm{yr}$, whilst the observed 1998 data actually refer to a less frequent flood event; and (b) our model only simulates damage in urban and peri-urban areas, whilst agricultural damages are also a major component of total damages in Bangladesh. For example, according to World Bank (2010) about a third of the damages in 1998 were in the agricultural sector. The population method estimate, on the other hand, somewhat overestimates the damages. Again, this is not surprising since the reported damages are direct damages to assets, whilst an estimate of affected GDP implicitly entails a larger pool of indirect losses.

The results in this application show that, although the global hydrology is solved at a coarse resolution, our application of the framework can provide information that is consistent with the spatial scale at which fluvial floods occur $\left(\sim 1 \mathrm{~km}^{2}\right)$.

\section{Discussion}

Our GLOFRIS implementation is just one model cascade that could be followed, and the application of this framework with another cascade will affect the results of our risk estimates due to aleatory uncertainty (due to natural and anthropogenic variability) and epistemic uncertainty, which is the effect of incomplete knowledge of the system (Apel et al., 2004). All components of the framework could be replaced by other models and methods to improve the model cascade, or could be run with other or multiple feasible parameter sets to estimate uncertainty (Di Baldassarre et al., 2010). For instance, another model cascade, limited to flood hazard only, was presented recently by Pappenberger et al. (2012). In cases in which risk is expressed as a fractional change from one place to the other or one period to the other, the sensitivity to the chosen model cascade is likely to be smaller than a case where indicators are used that are directly related to physically measurable units in a certain location (e.g. damage in US\$ PPP). In this case the absolute uncertainty due to model choices becomes more important to address. In this discussion we focus on the impact of some of the choices made in the application of our framework, and discuss additional choices that could be varied in future research.

\subsection{Climate input uncertainty}

The choice was made to run PCR-GLOBWB over a $30 \mathrm{yr}$ period, based on a combination of CRU and ERA40 data. This assumes that the CRU-ERA40 data are representative for the current climate and that $30 \mathrm{yr}$ is a long enough period to establish the required extreme value probability distribution. Extreme probability distributions are non-Gaussian in nature, which makes in particular the tails of the probability distribution uncertain (see e.g. Ruff and Neelin, 2012) and will become more accurate when a longer time series can be used. The required forcing of candidate hydrological models generally consists of global precipitation, temperature, and potential evaporation, the latter often in turn made dependent on net incoming short-wave radiation, long-wave radiation, temperature, wind speed, and humidity. Candidate input datasets should preserve long-term averages as well as temporal variability. A number of potentially suitable datasets exist, however all datasets may still suffer from errors due to poor sampling, undercatch (Biemans et al., 2009; Weedon et al., 2011), or limited representation of variability. How sensitive our results are to the choice of the dataset is yet to be investigated. It should be kept in mind that the goal of a global flood risk analysis is to identify factors such as spatial differences in risk and changes in risk given certain projected scenarios. It is therefore important to consider that bias in the input dataset may impact on the absolute results, but is likely to impact comparative results from place to place or scenario to scenario to a lesser degree, as long as a globally consistent modelling cascade is used. In future work, we will investigate this sensitivity by running our model with the WaterMIP dataset from the EU-WATCH project group (Weedon et al., 2011) as well as the ERAInterim-GPCP dataset (Balsamo et al., 2010). The WaterMIP set is also based on CRU and ERA40 but also includes the GPCP rainfall data to correct the monthly accumulated rainfall. Furthermore, a longer time period is used, which will result in a more accurate description of the extreme value probability distribution. The ERAInterim-GPCP dataset combines the Global Precipitation Climatology Project (GPCP) dataset of monthly rainfall observations, based on both in situ and satellite observations (Huffman et al., 2009) with the recent ERA-Interim re-analysis rainfall time series. 


\subsection{Hydrological model uncertainty}

Although the chosen hydrological model has been rigorously validated over many regions using a number of data sources, many other hydrological models exist that provide similar outputs as PCR-GLOBWB. In the Water Model Intercomparison Project (WaterMIP), considerable work has been carried out to compare and explain differences between global hydrological models and land surface models (Haddeland et al., 2011). The closest to the required information for flood risk estimation is the comparison of runoff. WaterMIP has compared the runoff from different models on annual and monthly timescales, and revealed considerable differences between all models considered. In this comparison, it should be noted that the models used in the WaterMIP project differ considerably in their goal. For instance, the Lund-JenaPotsdam managed Land (LPJmL) model (Bondeau et al., 2007; Rost et al., 2008) is designed for the purpose of vegetation type simulations. The runoff generation processes may therefore be simplified to a degree that is sufficient for modelling the vegetation and related moisture stores. The runoff generation process is modelled as a saturation excess function, which means that runoff does not gradually increase with increasing moisture state, but instead occurs only when full saturation is reached. For monthly accumulated runoff values, this is not necessarily problematic, but for shorter timescales at which flood genesis is relevant, such detail in hydrological processes is mandatory and a non-linear function with soil moisture is required. Model comparisons such as WaterMIP at the moment are focusing on river flows at large (e.g. monthly or seasonal) timescales. However, in such comparisons, more emphasis should be paid to the reproduction of flood genesis and the shape of the hydrograph in general, in order to tailor selections of model candidates for risk assessments of extreme events. This has so far not been considered in comparison studies of global hydrological models and is therefore still an open issue in this paper. Studying the behaviour of hydrological models during extremes may be done by using hydrograph signatures, such as auto-correlation, variance, and flow duration curves (see e.g. Gupta et al., 2008; Westerberg et al., 2011; Winsemius et al., 2009). To address the sensitivity of the model choice, we advocate using a multi-model ensemble, where the weight of each ensemble member could be chosen based on performance measures, which focus on the flood genesis. We invite other research groups to join this research effort with alternative hydrological models.

\subsection{Sensitivities in hydrological downscaling}

A number of choices are also required in the downscaling procedure. Figure 7 demonstrates for Bangladesh how the once-in-30 yr flood (i.e. the most extreme flood in the complete time series) is affected by the choice of a different threshold above which rivers are classified as flood-prone rivers (stream order 6 or 7), or a different return period threshold for the flood levels expected not to cause any inundation or damage in the river's surroundings (return period of 2 or $5 \mathrm{yr}$ ). It is evident that these choices have at least moderate influence on the results. A stream threshold above 6 , compared to 7, means that more river channels take part in the flooding process, and thus the water volume from a certain 0.5 degree pixel is distributed over a larger area. An obvious example of this is an artefact in the very south of the country, where a large flood-prone area appears when stream order above 6 is selected. This area is not flood prone when the threshold is set to 7 . The overall result is that a larger region becomes flood prone but that the water levels in these areas become somewhat lower.

Selecting a lower safety level (i.e. a lower return period of no flooding, with an associated flood volume) also results in a larger flood hazard, although this effect is smaller than the effect of changing the minimum Strahler order. The threshold flood volume at which no flooding may be expected represents a safety level, for example due to the presence of dikes. This volumetric threshold is a suitable way of dealing with present dikes, as long as (a) the dike is not dimensioned for very high safety standards such that a flood event will only occur with very high return periods far beyond the simulated time series (see Sect. 4.5); and (b) we can reasonably assume that flooding occurs due to levee overtopping rather than dike breaches. The risk due to dike breaches is of interest typically if safety standards are very high (e.g. in the Netherlands for the large rivers, a minimum $1250 \mathrm{yr}$ return period is maintained). In such cases, a more localized modeling approach with what-if scenarios for dike breaches is required (see e.g. de Moel et al., 2012).

The choice for the river threshold and the safety level should in fact be made differently per region of interest, depending on the physical characteristics of the river system and the level of (natural or man-made) protection against flooding. Preferably, the choices should be made based on local knowledge. In addition, the choices may be validated by comparison with remote sensing information, e.g. flood maps from the Dartmouth Flood Observatory.

Other downscaling approaches can also be used. For example, Neal et al. (2012) have developed a large-scale applicable dynamic modelling approach, which could be used to perform a more physically based downscaling, which not only preserves the mass balance but also momentum.

\subsection{Limitations of impact models}

In this study we have applied two separate methods for estimating flood risk on the basis of global hazard, exposure, and vulnerability data. One method is based on population density and GDP per capita, and the other on land use and estimated asset values. Both methodologies have limitations that result from their approaches and assumptions. 

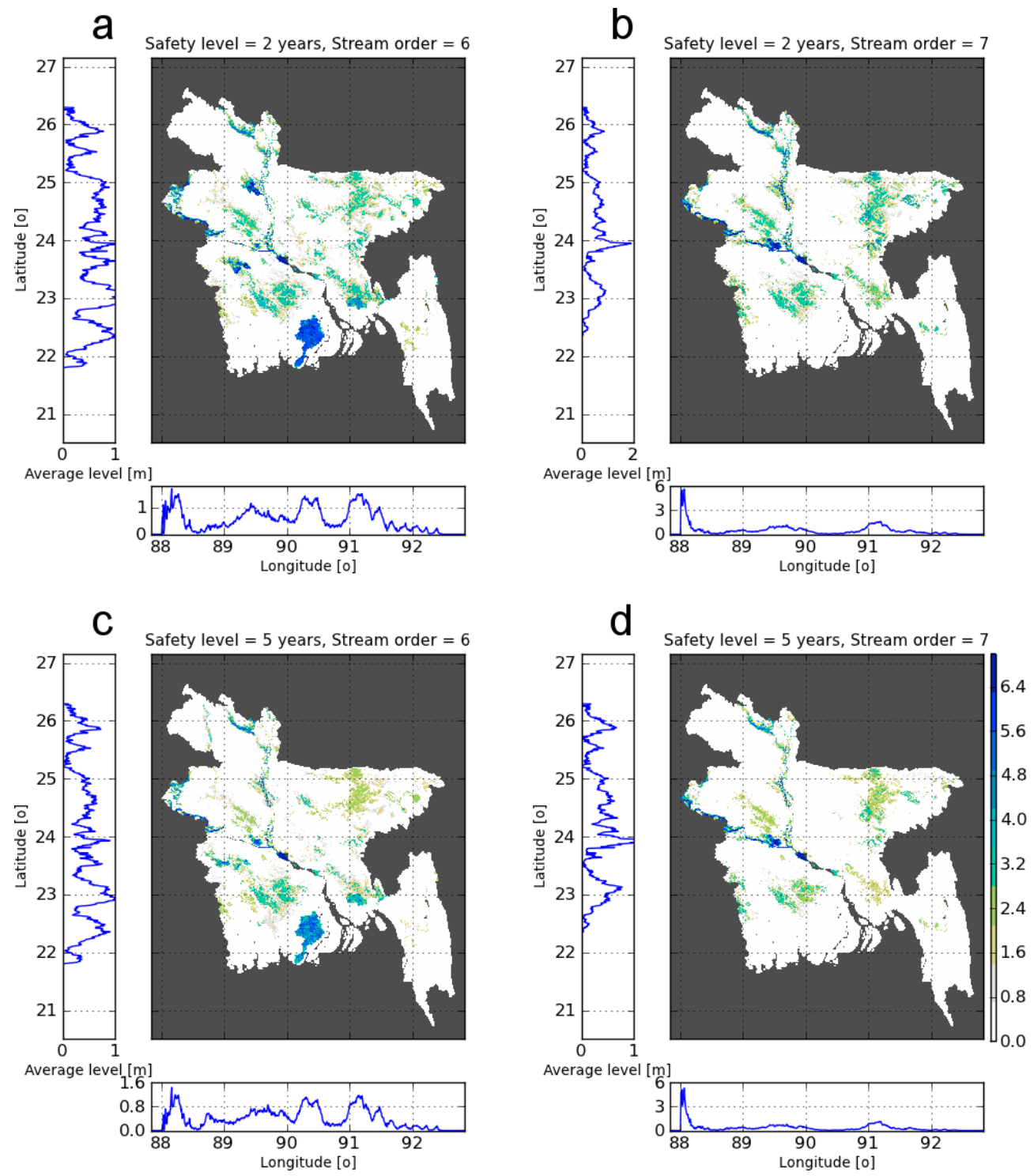

Fig. 7. The sensitivity of the downscaling to the 2 choices: (1) from which Strahler stream order do river floods occur?; and (2) at which minimum return period do floods start to cause damage? Each plot shows a top-view and zonal averages in longitudinal and latitudinal direction of inundation levels $[\mathrm{m}]$ at a $30 \mathrm{yr}$ return period. Each subfigure shows the results with different assumptions on the river size, and return periods at which river floods start to play a role.

The population method uses a linear relationship of GDP per capita to quantify the value of assets at risk of flooding. In reality, this relationship may be more complex. In addition, a longer timescale average GDP/population estimate rather than a snap shot in time would be more appropriate, given that our flood risk framework focuses on climatological risk estimates. Furthermore, the homogenous distribution of GDP over all areas within a country entails the assumption of equal productivity by each inhabitant. In reality, important sources for GDP are often focused on several specific sites or regions, especially in countries where a large part of the domestic product results from natural resource extraction (Hill, 2000; Jongman et al., 2012b).
The land use method also has the limitation that the estimated maximum damage values are directly linked to GDP per capita. Maximum damage values should ideally be calculated on the basis of more information, such as family income and property values. Furthermore, the land use method applies the same vulnerability (depth-damage) functions in each region, while in reality the true vulnerability will vary within and between countries (Jongman et al., 2012a; Merz et al., 2010). More research is needed to make spatial differentiations in vulnerability at the global scale, for example on the basis of estimated building material and quality (Apel et al., 2009). Obviously this requires more local information. 
Finally, the available spatial population and land use data make it difficult to produce consistent projections of future flood risk. Existing global models of future land use are limited in that they operate on a low resolution (e.g. $0.5^{\circ}$ or $50 \mathrm{~km})$ and focus predominantly on agriculture and vegetation (Verburg et al., 2011). The current understanding of urban expansion over time is limited and fragmented (Seto and Shepherd, 2009). However, ongoing research activities in this field (e.g. Letourneau et al., 2012; Seto et al., 2011) should mean that finer resolution global urban land cover models will become available in the short term.

\subsection{Limitations}

So far, we have applied our framework over a $30 \mathrm{yr}$ time series, under the assumption of a return period of non-flooding (in the Bangladesh case, this return period was set on $2 \mathrm{yr}$ ). This can only be done when the return period of non-flooding is considerably lower than the amount of simulated years available. In areas with high protection standards, the simulated time series are likely to be too short to establish a satisfying probability distribution of events. Therefore, the applicability of our framework is until now limited to areas with low protection standards. This is the case in most developing countries. These are also the areas where our framework is most interesting. Furthermore, as mentioned before, the relatively short $(30 \mathrm{yr})$ simulated time series results in a relatively small amount of samples in the tail of the extreme value distribution.

Man-made interactions with the river system, such as the operation of dams and reservoirs, and operation of weirs and controlled flooding (see e.g. Di Baldassarre et al., 2009) have not yet been taken into account. These could be included in future study, but with the risk of incorrectly estimating the operation during flood conditions. The impact of reservoir control could result in the reduction of floods if the controller has proper information at hand to decide upon pre-releases, but in many cases if such information is not at hand at the reservoir, they may result in larger floods if unexpected inflows are experienced.

The effect of levee breaks is also not included, which can have large impacts on flood patterns. For example, during the Pakistan floods in 2009 a large part of a major embankment was destroyed by the floods, causing a completely different flood pattern than what a model would simulate. This appeals for a more interactive approach to mapping flood hazards, which allows for what-if scenarios on the schematisation of the elevation profile throughout a case study area. Obviously, such what-if scenarios are not suited for a global approach such as presented here.

A further limitation so far is that whilst flood risk has been modelled as a function of flood hazard, exposure, and vulnerability, the vulnerability has been assumed to remain the same in time and space. Future developments in resilience and adaptation measures may however reduce vulnerability (e.g. due to increased in awareness, other building methods, flood warning procedures, and so on and so forth). On the other hand, such improvements in safety can also lead to further development in the flood plain, which pleads for a more human-water interacting approach to flood plain modelling (Di Baldassarre et al., 2013). Again, resilience and vulnerability are spatially diverse in nature and should be established using in situ information. This information may then be propagated into the damage functions. Such local information may be limited when considering large-scale applications.

Finally, we only demonstrated our method using one climate scenario, and two GCM models. If an in-depth investigation into the effects of climate change on flood risks is required, more scenarios, and in particular more GCM runs, should be considered, as the variability due to GCM selection is larger than the variability due to the scenario chosen (Sperna Weiland, 2011). Such an analysis is outside the scope of this paper.

\section{Conclusions}

The aim of our global flood risk assessment framework for river flooding is to provide flood risk maps using a globally consistent combination of models. This is done by producing hazard and exposure maps at an appropriate spatial scale, and combining these with vulnerability relationships, in order to create risk maps. In this paper, a $1 \times 1 \mathrm{~km}$ scale was used, because most of the global data used in this study (e.g. elevation, land cover, population, and urbanisation) are available at this spatial scale.

In this paper, we described a specific implementation of the framework called GLObal Flood Risks with IMAGE Scenarios. This implementation combines the global hydrological model PCR-GLOBWB, with a subgrid parameterised dynamic flow routing called DynRout and a flood extent downscaling algorithm to provide a distribution function of global flood hazard. GLOFRIS combines scenarios from the IMAGE instrument, downscaled with land use and population maps to $1 \times 1 \mathrm{~km}^{2}$, with a number of damage models to estimate exposure, with vulnerability in the form of depthdamage functions.

In this study we argued that besides the global hydrological models, downscaling to higher resolution than the typical resolution of global hydrological models (in the order of $50 \mathrm{~km}$ ) is required in order to perform a feasible combination between flood hazard on the one hand, and flood exposure and vulnerability on the other hand. This is because the spatial variability in both hazard and potential impacts may be much larger than the typical resolution of global hydrological models.

To demonstrate GLOFRIS, we applied the full modelling framework on the case study of Bangladesh. The study resulted in plausible river flood hazard maps and damage 
estimates, which were in the same order of magnitude as estimates from the global EM-DAT database and World Bank estimates. This demonstrates that the model approaches used as implementation of our framework provide satisfactory results.

Furthermore, we applied the framework using combinations of climate and socio-economic changes. Climate changes simulated by ECHAM and HadGEM A1B caused a relative increase in flood risk compared to current conditions of approximately a factor 3 . Socio-economic changes caused an additional relative increase of factor 10 over Bangladesh. This demonstration shows that our framework can be applied to rapidly estimate flood risk changes over large areas and significantly attribute these changes to hazard increase or decrease (i.e. due to climate change), and changes in potential impacts (i.e. due to socio-economic changes).

Currently, our framework has been implemented using one cascade of models. We highly recommend that this approach is extended towards a multi-model approach, where any component in the model cascade can be exchanged with another component. This is seen as a research opportunity.

\section{Appendix A}

\section{Description of PCR-GLOBWB dynamic routing}

For those cells that are identified as stream segments, discharge is calculated from the kinematic wave approximation of the Saint-Venant Equation (Chow, 1988). The continuity equation is

$\frac{\partial Q}{\partial x}+\frac{\partial A}{\partial t}=q$

and the momentum equation can be expressed by

$A=\alpha Q^{\beta}$

where $Q$ is the streamflow through the channel $\left[\mathrm{L}^{3} \mathrm{~T}^{-1}\right], A$ is the channel cross-section $\left[\mathrm{m}^{2}\right], q$ is the inflow-specific runoff per length of channel $\left[\mathrm{L}^{2} \mathrm{~T}^{-1}\right], x$ is the length along the channel [L], and $t$ is the elapsed time [T]. $q$ is here delivered by the water balance model, described above.

The coefficients $a$ and $b$ are obtained from Manning's equation (Chow, 1988):

$Q=\frac{R^{2 / 3} \sqrt{S}}{n} A$,

where $R$ is the hydraulic radius [L], $A$ is the cross-sectional surface $\left[\mathrm{L}^{2}\right], S$ is the energy gradient, in the kinematic wave approximation, this gradient is assumed to be equal to that of the river bed [-], and $n$ is Manning's roughness coefficient $\left[\mathrm{L}^{5 / 6} \mathrm{~T}^{-1}\right] . R$ can be substituted by $A / P$, where $P$ is the wetted perimeter [L] and Eq. (A2) rewritten in terms of $A$ :

$A=\left[\frac{n P^{2 / 3}}{\sqrt{S}}\right]^{3 / 5} Q^{3 / 5}$,
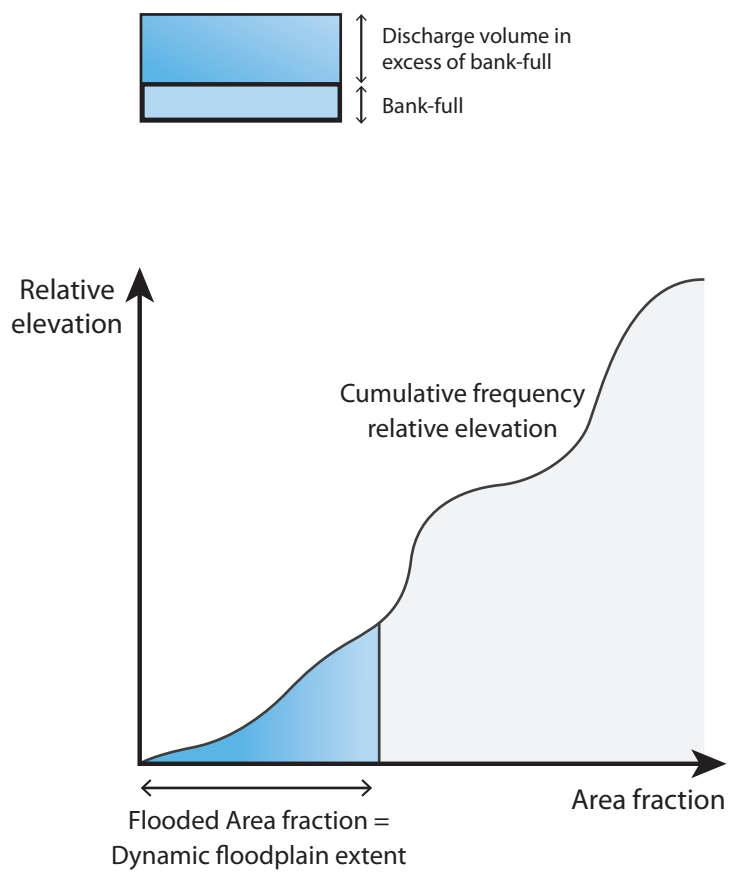

Fig. A1. Schematic of determining the static floodplain area and the dynamic floodplain extent (fraction flooded area) within a $0.5 \times 0.5^{\circ}$ cell based on bank-full discharge surface water level, actual surface water level and a $1 \times 1 \mathrm{~km}$ digital elevation model. The discharge volume in excess of bank-full, as shown in the top figure, is mapped onto the cumulative distribution of floodplain elevation, as shown in the bottom figure.

which gives

$\alpha=\left[\frac{n P^{2 / 3}}{S^{1 / 2}}\right]^{3 / 5}$,

and

$\beta=3 / 5$.

To ensure numerical stability, Eq. (A1) is applied for a variable number of sub-time steps per day that satisfy the Courant number everywhere.

For lake and reservoir cells, which can extend over several cells to form contiguous water bodies, discharge is calculated in analogy to the weir formula as the discharge over a rectangular cross section in this study, although a separate scheme can be introduced to simulate reservoir operations (Van Beek et al., 2011b). The outflow from lakes and reservoir provides the input hydrograph for the downstream river sections while lakes and reservoirs themselves are fed by stream flow where they intersect the river network.

PCR-GLOBWB includes two options to represent the fraction freshwater. In case it is fixed, the areas of lakes, reservoirs and floodplains are kept constant and floodplains and through flow wetlands (i.e. Niger inner delta) are treated 
as regular river stretches (albeit with an area and a resistance in terms of Manning's $n$ that is larger than those of the channel properties). If variable, the option used in this study, both river stretches and water bodies change their area during routing. Discharge volumes in excess of the maximum channel storage flood the adjacent land area, and pond an area with a relative elevation over the riverbed equivalent to the volume to be stored, which is derived from a cumulative distribution of relative elevations based on a $1 \times 1 \mathrm{~km}^{2}$ resolution (Fig. A1). Over the flooded area, this results in a mean flood depth but also an increased wetted perimeter. The resulting increase in hydraulic resistance ( $n$ in Eq. A3) generally will lead to longer travel times and larger associated flood volumes. Together with the required redistribution of flood waters, this leads to increased computation times. Thus, the schematisation of the freshwater surface area includes direct precipitation and evaporation, but does not include increased infiltration, as the soil hydrology is kept at a daily time step for computational efficiency.

Parameterisation of the flood model requires information to delineate lakes and reservoirs from rivers, which was taken from the GLWD1 dataset (Lehner and Döll, 2004), and a drainage direction map, which was based on the DDM30 (Döll and Lehner, 2002). Channel dimensions were derived from hydraulic relationships between bank-full discharge and channel geometry (Allen et al., 1994) and regionalised on the basis of the relationship between global climate indicators and the observed bank-full discharge for 296 stations of the RivDis dataset (http://www.rivdis.sr.unh.edu/). Channel length was derived directly from the average cell length multiplied by a tortuosity factor of 1.3 . The channel gradient was derived from the $1 \times 1 \mathrm{~km}$ elevations from the Hydro1k (Verdin, 2011) associated with the perennial streams from the VMAP database (http://geoengine.nima.mil/). The same elevation dataset was used to derive the subgrid cumulative elevation distribution. Starting from a subcatchment distribution within each $0.5^{\circ}$ cell area centred on the perennial streams, the relative height above the floodplain of each $1 \mathrm{~km}$ cell was calculated. For each cell, the aggregated subgrid distribution was then described by selected percentiles (0.01, 0.05 and 0.1 through 1.0 by increments of 0.1 ) and represented by a smooth continuous function following the approach of Kavetski and Kuczera (2007). In the absence of detailed information on Manning's $n$, characteristic values of 0.04 and 0.10 were assigned to channel and floodplains, respectively.

Acknowledgements. We acknowledge the Directorate General of International Cooperations under the Ministry of Foreign affairs, The Netherlands for their funding of this research. Furthermore, part of this research was funded under a VENI grant from the Netherlands Organisation for Scientific Research (NWO). NWO is also greatly acknowledged for this support. Finally, we thank G. R. (Robert) Brakenridge of the University of Colorado, Community Surface Dynamics Modeling System, for supplying the validation data from the Dartmouth Flood Observatory archive over the Ganges Brahmaputra region.

Edited by: G. Di Baldassarre

\section{References}

Aerts, J. C. J. H., Sprong, T., and Bannink, B. A.: Aandacht voor veiligheid, Leven met Water, Klimaat voor Ruimte, DG Water, Amsterdam, the Netherlands, 2008.

Allen, P. M., Arnold, J. C., and Byars, B. W.: Downstream Channel Geometry for use in planning-level models, J. American Water Resour. Assoc., 30, 663-671, doi:10.1111/j.17521688.1994.tb03321.x, 1994.

Apel, H., Thieken, A. H., Merz, B., and Blöschl, G.: Flood risk assessment and associated uncertainty, Nat. Hazards Earth Syst. Sci., 4, 295-308, doi:10.5194/nhess-4-295-2004, 2004.

Apel, H., Aronica, G. T., Kreibich, H., and Thieken, A. H.: Flood risk analyses-how detailed do we need to be?, Nat. Hazards, 49, 79-98, 2009.

Balsamo, G., Bousetta, P., Ferranti, L., and Lopez, P.: Evaluation of ERA-Interim and ERA-Interim-GPCP-rescaled precipitation over the U.S.A., ECMWF, Reading, UK, available at: http://www.ecmwf.int/publications/library/do/references/list/ 782009 (last access: 16 May 2013), 2010.

Berrisford, P., Dee, D., Fielding, K., Fuentes, M., Kallberg, P., Kobayashi, S., and Uppala, S.: The ERA-Interim Archive, Technical Report, European Centre for Medium-Range Weather Forecasts, Reading, UK, available at: http://www.ecmwf.int/ publications/library/do/references/list/782009 (last access: 22 January 2013), 2009.

Biemans, H., Hutjes, R. W. A., Kabat, P., Strengers, B. J., Gerten, D., and Rost, S.: Effects of Precipitation Uncertainty on Discharge Calculations for Main River Basins, J. Hydrometeorol., 10, 1011-1025, 2009.

Bierkens, M. F. P. and Van Beek, L. P. H.: Seasonal Predictability of European Discharge: NAO and Hydrological Response Time, J. Hydrometeorol., 10, 953-968, 2009.

Blyth, K.: Floodnet: a telenetwork for acquisition, processing and dissemination of earth observation data for monitoring and emergency management of floods, Hydrol. Process., 11, 1359-1375, doi:10.1002/(SICI)1099-1085(199708)11:10<1359::AIDHYP529>3.0.CO;2-6, 1997.

Bondeau, A., Smith, P. C., Zaehle, S., Schaphoff, S., Lucht, W., Cramer, W., Gerten, D., Lotze-Campen, H., Muller, C., Reichstein, M., and Smith, B.: Modelling the role of agriculture for the 20th century global terrestrial carbon balance, Global Change Biol., 13, 679-706, doi:10.1111/j.13652486.2006.01305.x, 2007.

Bouwman, A. F., Kram, T., and Klein Goldewijk, K.: Integrated modelling of global environmental change, An overview of IMAGE 2.4, The Netherlands Environmental Assessment Agency, 2006.

Brakenridge, G. R., Anderson, E., Nghiem, S. V., Caquard, S., and Shabaneh, T.: Flood warnings, flood disaster assessments, and flood hazard reduction: the roles of orbital remote sensing, in: Proceedings of the 30th International Symposium on Remote Sensing of the Environment, Honolulu, Hawai'i., 2003. 
Carsell, K. M., Pingel, N. D., and Ford, D. T.: Quantifying the Benefit of a Flood Warning System, Nat. Hazards Rev., 5, 131-140, doi:10.1061/(ASCE)1527-6988(2004)5:3(131), 2004.

Chow, V.-T.: Open channel hydraulics, McGraw-Hill Book Company, New York, 1988.

CIESIN and CIAT: Global Rural-Urban Mapping Project (GRUMP), Center for International Earth Science Information Network (CIESIN), Columbia University and Centro Internacional de Agricultura Tropical (CIAT), available at: http://sedac.ciesin.columbia.edu/gpw (last access: 2012), 2009.

De Bruijn, K. M.: Resilience and flood risk management; a systems approach applied to lowland rivers, $\mathrm{PhD}$ thesis, Delft, University of Technology, Delft, The Netherlands, 2005.

Decharme, B., Douville, H., Prigent, C., Papa, F., and Aires, F.: A new river flooding scheme for global climate applications: Off-line evaluation over South America, J. Geophys. Res., 113, D11110, doi:10.1029/2007JD009376, 2008.

de Moel, H., Asselman, N. E. M., and Aerts, J. C. J. H.: Uncertainty and sensitivity analysis of coastal flood damage estimates in the west of the Netherlands, Nat. Hazards Earth Syst. Sci., 12, 10451058, doi:10.5194/nhess-12-1045-2012, 2012.

Di Baldassarre, G., Castellarin, A., Montanari, A., and Brath, A.: Probability-weighted hazard maps for comparing different flood risk management strategies: a case study, Nat. Hazards, 50, 479_ 496, 2009.

Di Baldassarre, G., Schumann, G., Bates, P. D., Freer, J. E., and Beven, K. J.: Flood-plain mapping: a critical discussion of deterministic and probabilistic approaches, Hydrol. Sci. J., 55, 364376, doi:10.1080/02626661003683389, 2010.

Di Baldassarre, G., Kooy, M., Kemerink, J. S., and Brandimarte, L.: Towards understanding the dynamic behaviour of floodplains as human-water systems, Hydrol. Earth Syst. Sci. Discuss., 10, 3869-3895, doi:10.5194/hessd-10-3869-2013, 2013.

Döll, P. and Lehner, B.: Validation of a new global 30-min drainage direction map, J. Hydrol., 258, 214-231, doi:10.1016/S00221694(01)00565-0, 2002.

Ferreira, S., Hamilton, K., and Vincent, J. R.: Nature, Socioeconomics and Adaptation to Natural Disasters: New Evidence from Floods, SSRN eLibrary, available at: http://papers.ssrn.com/sol3/ papers.cfm?abstract_id=1876300 (last access: 22 May 2012), 2011.

Field, C. B., Barros, V., Stocker, T. F., Qin, D., Dokken, D., Ebi, K. L., Mastrandrea, M. D., Mach, K. J., Plattner, G.-K., Allen, S. K., Tignor, M., and Midgley, P. M.: Summary for policymakers, in Intergovernmental Panel on Climate Change - Special Report on Managing the Risks of Extreme Events and Disasters to Advance Climate Change Adaptation, Cambridge University Press, Cambridge and New York, 2011.

Green, C. H.: Coastal cities: assets at risk and depth-damage curves, Report, prepared for the OECD, Middlesex University, Middlesex, 2010.

Green, C., Viavattene, C., and Thompson, P.: Guidance for assessing flood losses, CONHAZ report, Flood Hazard Research Centre, Middlesex University, Middlesex, 2011.

Gupta, H. V., Wagener, T., and Liu, Y.: Reconciling theory with observations: elements of a diagnostic approach to model evaluation, Hydrol. Process., 22, 3802-3813, doi:10.1002/hyp.6989, 2008.
Haddeland, I., Clark, D. B., Franssen, W., Ludwig, F., Voß, F., Arnell, N. W., Bertrand, N., Best, M., Folwell, S., Gerten, D., Gomes, S., Gosling, S. N., Hagemann, S., Hanasaki, N., Harding, R., Heinke, J., Kabat, P., Koirala, S., Oki, T., Polcher, J., Stacke, T., Viterbo, P., Weedon, G. P., and Yeh, P.: Multimodel Estimate of the Global Terrestrial Water Balance: Setup and First Results, J. Hydrometeorol., 12, 869-884, doi:10.1175/2011JHM1324.1, 2011.

Herold, C. and Mouton, F.: Global flood hazard mapping using statistical peak flow estimates, Hydrol. Earth Syst. Sci. Discuss., 8, 305-363, doi:10.5194/hessd-8-305-2011, 2011.

Hill, H.: Intra-country regional disparities, in Proceedings of the Second Asian Development Conference, Asian Development Bank, Singapore, 2000.

Huffman, G. J., Adler, R. F., Bolvin, D. T., and Gu, G.: Improving the global precipitation record: GPCP Version 2.1, Geophys. Res. Lett., 36, L17808, doi:10.1029/2009GL040000, 2009.

IPCC: IPCC special report - Emissions scenarios - IPCC working group III, IPCC, available at: http://www. google.nl/url?sa=t\&rct=j\&q=ipcc\%20description $\% 20$ sres $\%$ 20scenarios \&source $=$ web $\& \mathrm{~cd}=1 \&$ ved $=0 \mathrm{CCMQFjAA} \& u r l=$ http $\% 3 \mathrm{~A} \% 2 \mathrm{~F} \% 2$ Fwww.ipcc.ch\%2Fpdf $\% 2$ Fspecial-reports $\%$ 2Fspm\%2Fsres-en.pdf\&ei=SL-iT9qbIqiQ0AWb-ujdCA\&usg= AFQjCNGJNUO_TN_vMIuY_TSM1Clt081GbQ (last access: 3 May 2012), 2000.

Jha, A. K., Bloch, R., and Lamond, J.: Cities and flooding: a guide to integrated urban flood risk management for the 21 st century, The World Bank, Washington DC, 2012.

Jongman, B., Kreibich, H., Bates, P. D., Barredo, J. I., Gericke, A., Apel, H., Neal, J., Aerts, J. C. J. H., and Ward, P. J.: Comparative flood damage model assessment: Towards a European approach, Geophys. Res. Abstr., EGU2012-7663, EGU General Assembly 2012, Vienna, Austria, 2012a.

Jongman, B., Ward, P. J., and Aerts, J. C. J. H.: Global exposure to river and coastal flooding - long term trends and changes, Glob. Environ. Change, 22, 823-835, doi:10.1016/j.gloenvcha.2012.07.004, 2012b.

Jonkman, S. N.: Loss of life estimation in flood risk assessment, Theory and applications, $\mathrm{PhD}$ thesis, Delft, University of Technology, Delft, The Netherlands, 2007.

Kaufmann, D., Kraay, A., and Mastruzzi, M.: The Worldwide Governance Indicators (WGI) project, available at: http:// info.worldbank.org/governance/wgi/index.asp, The World Bank, Washington DC, 2011.

Kavetski, D. and Kuczera, G.: Model smoothing strategies to remove microscale discontinuities and spurious secondary optima in objective functions in hydrological calibration, Water Resour. Res., 43, W03411, doi:10.1029/2006WR005195, 2007.

Klein Goldewijk, K., Beusen, A., Van Drecht, G., and De Vos, M.: The HYDE 3.1 spatially explicit database of human-induced global land-use change over the past 12,000 years, Global Ecol. Biogeogr., 20, 73-86, doi:10.1111/j.1466-8238.2010.00587.x, 2011.

Klijn, F., Baan, P. J. ., Bruijn, K. M. de, Kwadijk, J. C., and van Buren, R.: Overstromingsrisico's in Nederland in Een Veranderend Klimaat Verwachtingen, Schattingen En Berekeningen Voor Het Project Nederland Later, WL Delft Hydraulics, Delf., 2007.

Kummu, M., De Moel, H., Ward, P. J., and Varis, O.: How Close Do We Live to Water? A Global Analysis of Popula- 
tion Distance to Freshwater Bodies, PLoS ONE, 6, e20578, doi:10.1371/journal.pone.0020578, 2011.

Lehner, B. and Döll, P.: Development and validation of a global database of lakes, reservoirs and wetlands, J. Hydrol., 296, 1-22, doi:10.1016/j.jhydrol.2004.03.028, 2004.

Letourneau, A., Verburg, P. H., and Stehfest, E.: A land-use systems approach to represent land-use dynamics at continental and global scales, Environ. Model. Softw., 33, 61-79, 2012.

Meijer, J., Hilderink, H., and Lucas, P.: Exploring data and methods used for global modelling of the urban population and extent, The Netherlands Environmental Assessment Agency, Bilthoven, The Netherlands, 2006.

Merz, B., Kreibich, H., Schwarze, R., and Thieken, A.: Review article "Assessment of economic flood damage", Nat. Hazards Earth Syst. Sci., 10, 1697-1724, doi:10.5194/nhess-10-16972010, 2010.

Messner, F., Penning Rowsell, E. C., Green, C., Meyer, V., Tunstall, S. M., and Van der Veen, A.: Evaluating flood damages: guidance and recommendations on principles and methods, FLOODsite, Wallingford, UK, 2007.

Monirul Qader Mirza, M.: Three Recent Extreme Floods in Bangladesh: A Hydro-Meteorological Analysis, Nat. Hazards, 28, 35-64, doi:10.1023/A:1021169731325, 2003.

Munich Re: Topics Geo, natural catastrophes 2009: analyses, assessments, positions, Munich Reinsurance Company, Munich, Germany, 2010.

Neal, J., Schumann, G., and Bates, P.: A subgrid channel model for simulating river hydraulics and floodplain inundation over large and data sparse areas, Water Resour. Res., 48, W11506, doi:10.1029/2012WR012514, 2012.

New, M., Lister, D., Hulme, M., and Makin, I.: A high-resolution data set of surface climate over global land areas, Climate Res., $21,1-25,2002$.

Pappenberger, F., Dutra, E., Wetterhall, F., and Cloke, H. L.: Deriving global flood hazard maps of fluvial floods through a physical model cascade, Hydrol. Earth Syst. Sci., 16, 4143-4156, doi:10.5194/hess-16-4143-2012, 2012.

PBL: Towards a Global Integrated Sustainability Model, GISMO 1.0 status report, PBL Netherlands Environmental Assessment Agency, 2008.

Peduzzi, P., Dao, H., Herold, C., and Mouton, F.: Assessing global exposure and vulnerability towards natural hazards: the Disaster Risk Index, Nat. Hazards Earth Syst. Sci., 9, 1149-1159, doi:10.5194/nhess-9-1149-2009, 2009.

Petrescu, A. M. R., Van Beek, L. P. H., Van Huissteden, J., Prigent, C., Sachs, T., Corradi, C. a. R., Parmentier, F. J. W., and Dolman, A. J.: Modeling regional to global $\mathrm{CH}_{4}$ emissions of boreal and arctic wetlands, Global Biogeochem. Cy., 24, GB4009, doi:10.1029/2009GB003610, 2010.

Piani, C., Haerter, J. O., and Coppola, E.: Statistical bias correction for daily precipitation in regional climate models over Europe, Theor. Appl. Climatol., 99, 187-192, doi:10.1007/s00704-0090134-9, 2009.

Prigent, C., Papa, F., Aires, F., Rossow, W. B., and Matthews, E.: Global inundation dynamics inferred from multiple satellite observations, 1993-2000, J. Geophys. Res., 112, D12107, doi:10.1029/2006JD007847, 2007.

Rost, S., Gerten, D., Bondeau, A., Lucht, W., Rohwer, J., and Schaphoff, S.: Agricultural green and blue water consumption and its influence on the global water system, Water Resour. Res., 44, W09405, doi:10.1029/2007WR006331, 2008.

Ruff, T. W. and Neelin, J. D.: Long tails in regional surface temperature probability distributions with implications for extremes under global warming, Geophys. Res. Lett., 39, L04704, doi:10.1029/2011GL050610, 2012.

Schneider, A., Friedl, M. A., and Potere, D.: A new map of global urban extent from MODIS satellite data, Environ. Res. Lett., 4, 044003, doi:10.1088/1748-9326/4/4/044003, 2009.

Seto, K. C. and Shepherd, J. M.: Global urban land-use trends and climate impacts, Current Opinion Environ. Sustain., 1, 89-95, doi:10.1016/j.cosust.2009.07.012, 2009.

Seto, K. C., Fragkias, M., Güneralp, B., and Reilly, M. K.: A Meta-Analysis of Global Urban Land Expansion, PLoS ONE, 6, e23777, doi:10.1371/journal.pone.0023777, 2011.

Smith, D. I.: Flood damage estimation - A review of urban stagedamage curves and loss functions, Water SA, 20, 231-238, 1994

Sperna Weiland, F. C.: Hydrological impacts of climate change? interpretation of uncertainties introduced by global models of climate and hydrology, Utrecht Studies in Earth Sciences, 006, available at: http://igitur-archive.library.uu.nl/dissertations/ 2011-1130-200336/UUindex.html (last access: 12 June 2012), 2011.

Sperna Weiland, F. C., van Beek, L. P. H., Kwadijk, J. C. J., and Bierkens, M. F. P.: The ability of a GCM-forced hydrological model to reproduce global discharge variability, Hydrol. Earth Syst. Sci., 14, 1595-1621, doi:10.5194/hess-14-15952010, 2010.

Strahler, A. N.: Handbook of Applied Hydrology, edited by: Chow, V. T., 4-39, 4-76, McGraw-Hill, New York, 1964.

Tapsell, S. M., Penning-Rowsell, E. C., Tunstall, S. M. and Wilson, T. L.: Vulnerability to Flooding: Health and Social Dimensions, Phil. Trans. R. Soc. Lond. A, 360, 1511-1525, doi:10.1098/rsta.2002.1013, 2002.

UNISDR: Hyogo Framework for Action 2005-2015: Building the Resilience of Nations and Communities to Disasters, United Nations, Kobe, Japan, 2005.

UNISDR: Global Assessment Report on Disaster Risk Reduction, Risk and Poverty in a Changing Climate, United Nations International Strategy for Disaster Reduction Secretariat, Geneva, 2009.

UNISDR: Global Assessment Report on Disaster Risk Reduction, Revealing Risk, Redefining Development, United Nations International Strategy for Disaster Reduction Secretariat, Geneva, 2011.

Uppala, S. M., Kallberg, P. W., Simmons, A. J., Andrae, U., Bechtold, V. da C., Fiorino, M., Gibson, J. K., Haseler, J., Hernandez, A., Kelly, G. A., Li, X., Onogi, K., Saarinen, S., Sokka, N., Allan, R. P., Andersson, E., Arpe, K., Balmaseda, M. A., Beljaars, A. C. M., Berg, L. van de, Bidlot, J., Bormann, N., Caires, S., Chevallier, F., Dethof, A., Dragosavac, M., Fisher, M., Fuentes, M., Hagemann, S., Holm, E., Hoskins, B. J., Isaksen, L., Janssen, P. A. E. M., Jenne, R., McNally, A. P., Mahfouf, J.-F., Morcrette, J.-J., Rayner, N. A., Saunders, R. W., Simon, P., Sterl, A., Trenberth, K. E., Untch, A., Vasiljevic, D., Viterbo, P., and Woollen, J.: The ERA-40 re-analysis, Q. J. Roy. Meteorol. Soc., 131, 2961-3012, doi:10.1256/qj.04.176, 2005.

Van Beek, L. P. H. and Bierkens, M. F. P.: The global hydrological model PCR-GLOBWB: conceptualization, parameterization and verification, Dept. of Physical Geography, Utrecht Uni- 
versity, Utrecht, available at: http://vanbeek.geo.uu.nl/suppinfo/ vanbeekbierkens2009.pdf (last access: 16 May 2013), 2009.

Van Beek, L. P. H., Wada, Y., and Bierkens, M. F. P.: Global monthly water stress: 1. Water balance and water availability, Water Resour. Res., 47, W07517, doi:10.1029/2010WR009791, 2011a.

Van Beek, L. P. H., Wada, Y., and Bierkens, M. F. P.: Global monthly water stress: I. Water balance and water availability., Water Resour. Res., 47, W07517, doi:10.1029/2010WR009791, 2011 b.

Verburg, P. H., Neumann, K., and Nol, L.: Challenges in using land use and land cover data for global change studies, Global Change Biol., 17, 974-989, doi:10.1111/j.13652486.2010.02307.x, 2011.

Verdin, K. L.: ISLSCP II HYDRO1k Elevation-derived Products, in ISLSCP Initiative II Collection. Data set, Oak Ridge National Laboratory Distributed Active Archive Center, Oak Ridge, Tennessee, USA, available at: http://daac.ornl.gov/ (last access: 16 May 2013), 2011.

Verkade, J. S. and Werner, M. G. F.: Estimating the benefits of single value and probability forecasting for flood warning, Hydrol. Earth Syst. Sci., 15, 3751-3765, doi:10.5194/hess-15-37512011, 2011.

Van Vuuren, D. P., Lucas, P. L., and Hilderink, H.: Downscaling drivers of global environmental change: Enabling use of global SRES scenarios at the national and grid levels, Global Environ. Change, 17, 114-130, doi:10.1016/j.gloenvcha.2006.04.004, 2007.

Wada, Y., Van Beek, L. P. H., and Bierkens, M. F. P.: Nonsustainable groundwater sustaining irrigation: A global assessment, Water Resour. Res., 48, W00L06, doi:10.1029/2011WR010562, 2012.

Weedon, G. P., Gomes, S., Viterbo, P., Shuttleworth, W. J., Blyth, E., Österle, H., Adam, J. C., Bellouin, N., Boucher, O., and Best, M.: Creation of the WATCH Forcing Data and Its Use to Assess Global and Regional Reference Crop Evaporation over Land during the Twentieth Century, J. Hydrometeorol., 12, 823-848, doi:10.1175/2011JHM1369.1, 2011.
Weerts, A. H., Winsemius, H. C., and Verkade, J. S.: Estimation of predictive hydrological uncertainty using quantile regression: examples from the National Flood Forecasting System (England and Wales), Hydrol. Earth Syst. Sci., 15, 255-265, doi:10.5194/hess-15-255-2011, 2011.

Werner, M. G. F., Schellekens, J., and Kwadijk, J. C.: Flood Early Warning Systems for Hydrological (sub) catchments, in: Encyclopedia of Hydrological Sciences, vol. 1, 349-364, John Wiley \& Sons., 2005.

Westerberg, I. K., Guerrero, J.-L., Younger, P. M., Beven, K. J., Seibert, J., Halldin, S., Freer, J. E., and Xu, C.-Y.: Calibration of hydrological models using flow-duration curves, Hydrol. Earth Syst. Sci., 15, 2205-2227, doi:10.5194/hess-15-22052011, 2011.

Wilby, R. L., Beven, K. J., and Reynard, N. S.: Climate change and fluvial flood risk in the UK: more of the same?, Hydrol. Process., 22, 2511-2523, doi:10.1002/hyp.6847, 2008.

Winsemius, H. C., Schaefli, B., Montanari, A., and Savenije, H. H. G.: On the calibration of hydrological models in ungauged basins: A framework for integrating hard and soft hydrological information, Water Resour. Res., 45, W12422, doi:10.1029/2009WR007706, 2009.

World Bank: Economics of Adaptation to Climate Change, Bangladesh, World Bank, Washington DC, 2010.

World Bank: World development indicators, available at: http:// databank.worldbank.org/ddp/home.do, World Bank, Washington DC, 2012.

Yamazaki, D., Kanae, S., Kim, H., and Oki, T.: A physically based description of floodplain inundation dynamics in a global river routing model, Water Resour. Res., 47, W04501, doi:10.1029/2010WR009726, 2011. 